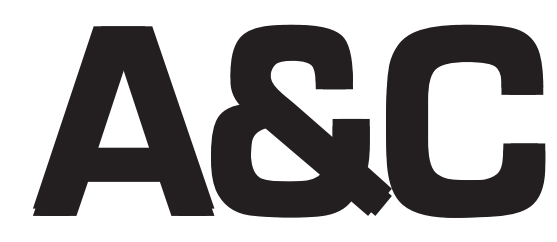

Revista de Direito Administrativo \& Constitucional

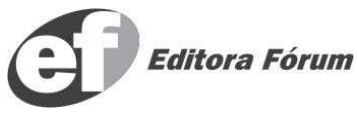

ISSN 1516-3210 


\section{A\&C REVISTA DE DIREITO ADMINISTRATIVO \& CONSTITUCIONAL}

\section{IPDA}

Instituto Paranaense

de Direito Administrativo

Direção Geral

Romeu Felipe Bacellar Filho

Direção Editorial

Paulo Roberto Ferreira Motta

Direção Executiva

Emerson Gabardo

Conselho de Redação

Edgar Chiuratto Guimarães

Adriana da Costa Ricardo Schier

Célio Heitor Guimarães

\section{Conselho Editorial}

Adilson Abreu Dallari (Brasil) Alice Gonzales Borges (Brasil) Antonello Tarzia (Itália)

Carlos Ari Sundfeld (Brasil)

Carlos Ayres Britto (Brasil)

Carlos Delpiazzo (Uruguai)

Cármen Lúcia Antunes Rocha (Brasil)

Celso Antônio Bandeira de Mello

(Brasil)

Clèmerson Merlin Clève (Brasil)

Clovis Beznos (Brasil)

Enrique Silva Cimma (Chile)

Eros Roberto Grau (Brasil)

Fabrício Motta (Brasil)

Guilhermo Andrés Muñoz - in memoriam

(Argentina)

Jaime Rodríguez-Arana Muñoz (Espanha)

Jorge Luís Salomoni - in memoriam
(Argentina)
José Carlos Abraão (Brasil)
José Eduardo Martins Cardoso (Brasil)
José Luís Said (Argentina)
José Mario Serrate Paz (Uruguai)
Juan Pablo Cajarville Peruffo (Uruguai)
Juarez Freitas (Brasil)
Julio Rodolfo Comadira - in memoriam
(Argentina)
Luís Enrique Chase Plate (Paraguai)
Lúcia Valle Figueiredo (Brasil)
Manoel de Oliveira Franco Sobrinho -
in memoriam (Brasil)
Marçal Justen Filho (Brasil)
Marcelo Figueiredo (Brasil)

\author{
Maria Cristina Cesar de Oliveira (Brasil) \\ Nelson Figueiredo (Brasil) \\ Odilon Borges Junior (Brasil) \\ Pascual Caiella (Argentina) \\ Paulo Eduardo Garrido Modesto (Brasil) \\ Paulo Henrique Blasi (Brasil) \\ Paulo Neves de Carvalho - in memoriam \\ (Brasil) \\ Paulo Ricardo Schier (Brasil) \\ Pedro Paulo de Almeida Dutra (Brasil) \\ Regina Maria Macedo Nery Ferrari (Brasil) \\ Rogério Gesta Leal (Brasil) \\ Rolando Pantoja Bauzá (Chile) \\ Sérgio Ferraz (Brasil) \\ Valmir Pontes Filho (Brasil) \\ Weida Zancaner (Brasil) \\ Yara Stropa (Brasil)
}

A246 A\&C Revista de Direito Administrativo \& Constitucional. ano 3, n. 11, jan./mar. 2003. Belo Horizonte: Fórum, 2003.

Trimestral

ano 1, n. 1, 1999 até ano 2, n. 10, 2002 publicada pela Editora Juruá em Curitiba

ISSN 1516-3210

1. Direito Administrativo. 2. Direito Constitucional. I. Fórum.

CDD: 342

CDU: 33.342

(C) 2008 Editora Fórum Ltda.

Todos os direitos reservados. É proibida a reprodução total ou parcial, de qualquer forma ou por qualquer meio eletrônico ou mecânico, inclusive através de processos xerográficos, de fotocópias ou de gravação, sem permissão por escrito do possuidor dos direitos de cópias (Lei nº 9.610, de 19.02.1998).

Editora Fórum Ltda

Editor responsável: Luís Cláudio Rodrigues Ferreira

Av. Afonso Pena, 2770 - 15\%16ªndar - Funcionários

CEP 30130-007 - Belo Horizonte/MG - Brasil

Coordenação editorial: Olga M. A. Sousa

Tel.: 08007043737

Internet: www.editoraforum.com.br

Pesquisa jurídica: Fátima Ribeiro - OAB/MG 74868

Revisora: Lourdes Nascimento

Projeto gráfico e diagramação: Luis Alberto Pimenta

e-mail: editoraforum@editoraforum.com.br

Bibliotecária: Fernanda de Paula Moreira - CRB 2900 - 6a região

Esta publicação está indexada no Ulrich's Periodicals Directory

Os conceitos e opiniões expressas nos trabalhos assinados são de responsabilidade exclusiva de seus autores.

Impressa no Brasil / Printed in Brazil

Distribuída em todo o Território Nacional 


\title{
O contrato de concessão de serviço público
}

Carlos Eduardo Thompson Flores Lenz

Desembargador Federal do TRF da $4^{a}$ Região.

\begin{abstract}
Resumo: O presente artigo versa sobre o contrato de concessão de serviço público. Inicialmente o tema da concessão de serviço público é abordado diante das disposições legais e conceituais. Em seguida, são analisados alguns acórdãos que tratam sobre o contrato de concessão e o equilíbrio econômicofinanceiro. Sob o enfoque da doutrina e da jurisprudência, é analisada a reversão dos bens na concessão. Aborda-se sobre a encampação como uma das modalidades de extinção da concessão de serviço público, analisando aspectos no tocante a indenização, forma de pagamento e critérios para fixação. Por fim, apresentam-se resumidamente alguns pontos principais tratados ao longo do trabalho.
\end{abstract}

Palavras-chave: Contrato de concessão de serviço público. Equilíbrio econômico-financeiro. Reversão dos bens na concessão. Encampação. Extinção da concessão do serviço público.

Sumário: 1 Aspectos da concessão de serviço público - 2 Os poderes do concedente e o equilíbrio econômico-financeiro do contrato de concessão. A intervenção judicial. Doutrina e jurisprudência - 3 A reversão dos bens na concessão - 4 A encampação e a justa indenização ao concessionário 5 Conclusão

\section{Aspectos da concessão de serviço público}

Consoante dispõe o art. 175 da Lei Maior, incumbe ao Poder Público - União, Estados e Municípios -, diretamente ou mediante o regime de concessão ou permissão, a prestação de serviços públicos, observado o disposto em lei e a forma da outorga, ou seja, sempre através da licitação.

Regulamentando o citado dispositivo constitucional, foram editadas as Leis $\mathrm{n}^{\circ} 8.987 / 95$ e $^{\circ} 9.074 / 95$, disciplinando, de forma exaustiva, tanto o procedimento da licitação para a concessão de serviço público quanto as regras de elaboração do próprio contrato.

Assim, a Lei $\mathrm{n}^{\mathrm{o}}$ 8.987/95 constitui verdadeiro Estatuto Geral das Concessões e Permissões de serviços públicos no País, com aplicação em todo o território nacional.

A concessão de serviços públicos, portanto, reveste a natureza de contrato administrativo mediante o qual o Poder Público transfere ao concessionário, pessoa jurídica de direito privado, o exercício de determinados serviços para que os execute em seu nome, arcando com o risco

A\&C R. de Dir. Administrativo \& Constitucional, Belo Horizonte, ano 8, n. 33, p. 161-192, jul./set. 2008 
do empreendimento, mas sob a constante fiscalização do poder concedente, nos termos da lei, do contrato e do respectivo edital de licitação.

A respeito, anota o saudoso Ministro Carlos Thompson Flores, em conhecido parecer, verbis:

3.1 A concessão, como acentuam todos os autores, é a transferência da execução de um serviço público afeto ao Poder Público, a um particular, através de delegação contratual.

O contrato de concessão, meio próprio para instituí-lo, nada mais é que um ajuste de direito público, bilateral, oneroso, comutativo e realizado intuito personae (Mário Mazagão, Natureza Jurídica da Concessão de Serviço Público, 1933, p. 101)

3.2 A permissão, diversamente, não é contrato, é ato administrativo unilateral, discricionário e precário, pelo qual o Poder Público — ou seu delegado faculta ao particular a execução de serviços de interesse coletivo, e nas condições impostas pela Administração (Hely Lopes Meirelles, Direito Administrativo Brasileiro, Ed. RT, 1964, p. 328).

4. A diversidade de situações, como não poderia deixar de ser, derivam e decorrem conseqüências jurídicas que os autores indicam e os tribunais reconhecem, na sua aplicação (Hely Lopes Meirelles, Estudos e Pareceres de Direito Público, v. I/441-444 e ss., Ed. RT, 1971). Aí ficaram indicados numerosos julgados, tanto do Supremo Tribunal, como dos Tribunais Estaduais.

5. O que, porém, interessa, e impõe seja acentuado, é que a permissão, pelas circunstâncias de que se reveste, especialmente pelo aspecto unilateral, discricionário e precário, com prazos reduzidos, e isto quando os institui, o que nem sempre ocorre, jamais proporciona a reversão dos bens utilizados no serviço e adquiridos com o capital do permissionário. A concessão, ao contrário, a justifica, porque arrima-se no contrato, o qual, na generalidade dos casos, a institui expressamente.

Mas, ainda que não tenha sido objeto de cláusula especial, ela é presumida, pela própria índole do ajuste.

Seu fundamento central reside, em princípio, no imperativo da continuidade do serviço público, como acentuou o egrégio STF, invocando o ensinamento de Chardenet, citado por Gaston Jéze (in RDA 40/321).

6. É mister, contudo, acrescentar que ditos bens, adquiridos com capital e recursos próprios do concessionário, posto que utilizados no serviço, continuam no seu domínio e posse, como assinala Francisco Campos, citando o magistério de Otto Mayer (Pareceres de Direito Administrativo, v. I/137); e somente dele se apartam para integrar o patrimônio do concedente, e sem qualquer ônus, ao findar o prazo estipulado no contrato.

6.1 A esse tempo, longo e sempre continuado, por via da arrecadação da tarifa, faz presumir, ante o valor que esta representa, deva estar totalmente amortizado o capital invertido.

6.2 A admitir-se indenização, em tal hipótese, seria aquinhoar-se o concessionário com duplo pagamento: um, à conta do recolhimento da tarifa,

A\&C R. de Dir. Administrativo \& Constitucional, Belo Horizonte, ano 8, n. 33, p. 161-192, jul./set. 2008 
calculada sempre seu valor permita, além do lucro, a amortização do capital, e outro, à custa do concedente. Importaria tal proceder injustificado enriquecimento. Daí que, na ultimação do prazo contratual, a conseqüência necessária ser a reversão, totalmente gratuita, graciosa, sem qualquer pagamento.

6.3 Inobstante, se antecipada a retomada, antes de findo o prazo, e sem culpa do concessionário, a indenização se impõe, reparando os prejuízos que tal procedimento tenha acarretado.

6.4 Por isso, com propriedade, acentuou o Prof. Celso Antônio Bandeira de Mello, em sua festejada monografia A Prestação de Serviços Públicos e a Administração Indireta, Ed. RT, 1973, p. 51, verbis: “... Com efeito a amortização paulatina do capital investido pelo concessionário e os lucros previstos correm ao longo de uma dilação temporal. Daí que o Poder Público, devendo garantir o equilíbrio econômico-financeiro, por ser de natureza contratual, encerrará a concessão quando queira, mas garantirá a "expressão econômica" que se realizaria ao longo de certo prazo: aquele tomado como referência do seu valor. Portanto, compensará as importâncias que deixarão de ser recebidas e o restante do capital não amortizado". Outra não foi a orientação perfilhada pelo E. Supremo Tribunal Federal no julgamento do MS 17.957-DF, em 6.12.67 (in RTJ 46/144). ${ }^{1}$

\section{Os poderes do concedente e o equilíbrio econômico-financeiro do contrato de concessão. A intervenção judicial. Doutrina e jurisprudência}

Ao proferir voto no Agravo Regimental no AI no 2004.04.01.017706-

6/PR, julgado pela $3^{\mathrm{a}}$ Turma do TRF $/ 4^{\mathrm{a}}$ Região, anotei, verbis:

A doutrina é uniforme no admitir que o poder de alteração e rescisão unilateral do contrato administrativo é inerente à Administração Pública, podendo ser exercido ainda que nenhuma cláusula expressa o consigne, porém, a alteração somente pode atingir as denominadas cláusulas regulamentares, isto é, aquelas que dispõem sobre o objeto do contrato e o modo de sua execução.

Contudo, no que concerne às cláusulas econômicas, ou seja, aquelas que estabelecem a remuneração e os direitos do contratado perante a Administração e dispõem acerca da equação econômico-financeira do contrato administrativo, estas são inalteráveis, unilateralmente, pelo Poder Público sem que se proceda à devida compensação econômica do contratado, visando restabelecer o equilíbrio financeiro inicialmente ajustado entre as partes.

Esse o magistério do saudoso jurista Hely Lopes Meirelles, in Licitação e Contrato Administrativo, 9a edição, Revista dos Tribunais, 1990, pp. 181/2.

É o que se encontra previsto nos arts. 37, XXI, e 175, III, da CF/88, bem como no art. $9^{\circ}, \S 4^{\circ}$, da Lei $n^{\circ} 8.987 / 95$.

\footnotetext{
1 FLORES, Carlos Thompson. Desapropriação: empresa de ônibus. Parecer publicado na Revista de Direito Público, n. 95, 44-45. Consulte-se, ainda, sobre a matéria: BANDEIRA DE MELLO, Oswaldo Aranha. Natureza jurídica da Concessão do Serviço Público. Revista da Faculdade de Direito de Porto Alegre, ano 3, v. 2, p. 859-899, 1951.
}

A\&C R. de Dir. Administrativo \& Constitucional, Belo Horizonte, ano 8, n. 33, p. 161-192, jul./set. 2008 
Por outro lado, a concessionária, a teor do disposto no art. $6^{\circ}, \S 1^{\circ}$, da Lei $n^{\circ}$ $8.987 / 95$, tem o dever de satisfazer as condições de regularidade, continuidade, eficiência, segurança, atualidade, generalidade, cortesia na sua prestação e modicidade das tarifas.

Ora, o não atendimento desses encargos importa a aplicação de penalidades que podem originar, inclusive, a extinção da concessão.

Ademais, a revogação da liminar poderá comprometer a remuneração do serviço por meio da tarifa e, via de conseqüência, a garantia do equilíbrio econômicofinanceiro do contrato de concessão.

A respeito, leciona Celso Antônio Bandeira de Mello, em sua obra Prestação de Serviços Públicos e Administração Indireta, 2a edição - $3^{\mathrm{a}}$ tiragem, RT, 1987, pp. 47/8, verbis:

"No Brasil, a álea ordinária, ou seja, o único risco que o concessionário deve suportar sozinho cinge-se aos casos em que o concessionário haja atuado canhestramente, procedendo com ineficiência ou imperícia. Isto porque o art. 167 da Carta Constitucional do país estatui que a lei disporá sobre o regime das concessionárias de serviços públicos federais, estaduais e municipais, assegurando, entre outros, "tarifas que permitam a justa remuneração do capital, o melhoramento e a expansão dos serviços e assegurem o equilíbrio econômico e financeiro do contrato e fiscalização permanente e revisão periódica das tarifas, ainda que estipuladas em contrato anterior".

Ora, desde que o texto constitucional exige a adoção de tarifas que assegurem a justa remuneração do capital, impõe a garantia do equilíbrio econômico e financeiro e requer a revisão periódica das tarifas, está visto que sempre que ocorrer desequilíbrio na equação patrimonial - mesmo que derivado de oscilações de preços no mercado, insuficiência do número de usuários, ou de providências governamentais desempenhadas em nome de sua supremacia geral e sem relação com a posição jurídica de contratante que haja assumido - o Poder concedente deverá restabelecer o equilíbrio através da revisão de tarifas, de modo não só a restaurar-lhe os termos de igualdade mas ainda com fito de assegurar a justa retribuição do capital. Em outras palavras a Lei Magna impõe indiretamente a adoção, nas concessões, do regime de serviço pelo custo, dando a garantia de uma margem fixa de lucro."

Tais princípios restaram definitivamente incorporados no Direito Administrativo, sobretudo após a publicação do famoso aresto do Conselho de Estado da França, no caso da Companhia de Gás de Bordeaux, proferido em 1916, onde destacou-se a notável contribuição de Chardenet, verbis:

"Mais tout service public doit être organisé dans des conditions qui permettent de compter sur son fonctionnement d'une manière régulière, sans interruption, même momentanée, sans à-coups, passez-nous l'expression, et qui, en même temps, seront de nature à donner pleine satisfaction à ceux ayant à faire appel au service public, qui a étécréé pour eux, fonctionne régulièrement à leur égard. Voyez Syndicat des Propriétaires et Contribuables du quartier de la Croixde-Seguey-Tivoli, à Bordeaux, 21 décembre 1906. Il faut également, et cela dans l'intérêt général, que le service public soit à l'abri d'incessantes ou de trop fréquentes modifications qui, le plus souvent, apporteraient des troubles dans le fonctionnement ou la marche du service. Par suite, le service public doit être organisé pour un certain nombre d'années, réserve faite, bien entendu,

A\&C R. de Dir. Administrativo \& Constitucional, Belo Horizonte, ano 8, n. 33, p. 161-192, jul./set. 2008 
des perfectionnements qui pourraient y être apportés. Mais, au cours d'une période de temps un peu longue, bien des événements peuvent se produire, notamment la situation économique peut changer ou tout au moins se modifier. D'autre part, pour la bonne organisation et l'heureux fonctionnement d'un service public important, des dépenses élevées doivent être engagées, de gros capitaux doivent être immobilisés pour longtemps. Si nous prenons l'exemple du service d'éclairage, au début on aura à construire des usines, à établir des canalisations, etc. Plus tard, on aura à faire face à des frais d'entretien, de reconstruction, etc., à procéder à des renouvellements de matériel, souvent rendus nécessaires par quelque découverte scientifique ou par des perfectionnements des moyens de fabrication, dont les bénéficiairesdu service public doivent profiter. Au cours de l'execution du service, il faudra passer, presque toujours longtemps à l'avance, des marchés importants pour s'assurer les matières premières nécessaires à la fabrication du gaz. Les dépenses que l'on aura ainsi engagées seront amorties peu à peu et elles ne le seront que sur une période de temps assez longue. Pour éviter d'exposer la personne publique à tous les risques auxquels nous venons de faire allusion, - pour lui éviter d'engager ses ressources propres dans des opérations commerciales ou industrielles qu'impose le fonctionnement du service public, - pour lui éviter d'être obligée de recourir parfois à des emprunts plus ou moins onéreus, - on a songé à s'adresser à des tiers, particuliers ou sociétés, pour assurer le service public; on a songé à se décharger sur eux du soin d'assurer ce service. On est ainsi arrivé au contrat de concession." (In Revue Du Droit Public Et De La Science Politique, M. Giard \& E. Brière Editeurs, Paris, 1916, t. 33, pp. 220/1)

É o magistério autorizado de Georges Péquignot, verbis:

"Le cocontractant a droit à la rémunération inscrite dans son contrat. C'est le principe de la fixité du prix du contrat. Il n'a consenti son concours que dans l'espoir d'un certain bénéfice. Il a accepté de prendre à sa charge des travaux et des aléas qui, s'il n'avait pas voulu contracter, auraient été supportés par l'Administration: il est normal qu'il en soi rémunéré.

Il serait, par ailleurs, contraire à la règle de bonne foi, contraire aussi à toute sécurité des affaires et, de ce fait, dangereux pour l'état social et économique, que l'Administration puisse modifier, spécialment réduire, cette rémunération.”

E, mais adiante, conclui o mesmo autor, verbis:

“...l'Administration, lorsqu'elle modifie le contrat sur un point qui intéresse le service public, doit cependant maintenir son équation financière, c'està-dire, le bénéfice que le cocontractant espérait tirer de l'opération. A fortiori, toute autre modification étant mise à part, cette équation financière doit-elle être maintenue par l'impossibilité de réduire ou de supprimer directement la rémunération en vue de laquelle le cocontractant s'est engagé.

Ce principe est fondamental. Il doit être entendu très rigoureusement, car, application particulière de l'idée d'équation financière, il est la source de la sécurité juridique du cocontractant de l'Administration." (In Théorie Générale du Contrat Administratif, Éditions A. Pédone, Paris, 1945, pp. 434/5)

Confira-se, a respeito, recentes decisões do Eg. STJ, verbis:

“AGRAVO REGIMENTAL NA SUSPENSÃO DE LIMINAR N. 74 - PR (2004/

0031293-3) Relator: Ministro Edson Vidigal. Agravante: Empresa

A\&C R. de Dir. Administrativo \& Constitucional, Belo Horizonte, ano 8, n. 33, p. 161-192, jul./set. 2008 
Concessionária de Rodovias do Norte S/A - Econorte. Advogados: Romeu Felipe Bacellar Filho e outros. Agravado: Estado do Paraná. Procuradores: Sérgio Botto de Lacerda e outros. Requerido: Tribunal Regional Federal da $4^{\mathrm{a}}$ Região.

EMENTA: Suspensão de liminar. Tutela antecipada deferida para assegurar o reajuste de tarifas de pedágio pela empresa concessionária. 1. Não há como se concluir por ofensa à ordem ou à economia públicas em decisão concessiva de tutela antecipada que apenas assegurou o cumprimento de cláusula contratual livremente firmada entre as partes e não questionada administrativamente ou em juízo. 2. Perigo de dano inverso. O simples descumprimento de cláusulas contratuais por parte do governo local viola o princípio da segurança jurídica e inspira riscos nos contratos com a Administração. 3. Agravo regimental provido.

ACÓRDÃO: Vistos, relatados e discutidos estes autos, acordam os Ministros da Corte Especial, do Superior Tribunal de Justiça, na conformidade dos votos e das notas taquigráficas a seguir, por unanimidade, conhecer do agravo regimental e dar-lhe provimento, nos termos do voto do Sr. Ministro-Relator. Os Srs. Ministros Barros Monteiro, Francisco Peçanha Martins, Humberto Gomes de Barros, Cesar Asfor Rocha, Ari Pargendler, José Arnaldo da Fonseca, Fernando Gonçalves, Carlos Alberto Menezes Direito, Felix Fischer, Hamilton Carvalhido, Eliana Calmon, Paulo Gallotti, Franciulli Netto e Luiz Fux votaram com o Sr. Ministro-Relator. Não participou do julgamento o Sr. Ministro Antônio de Pádua Ribeiro. Ausentes, justificadamente, os Srs. Ministros Sálvio de Figueiredo Teixeira, José Delgado, Gilson Dipp e Francisco Falcão, sendo os três últimos substituídos, respectivamente, pelos Srs. Ministros Teori Albino Zavascki, Hélio Quaglia Barbosa e Castro Meira. Brasília (DF), $1^{\circ}$ de julho de 2004 (data do julgamento). Ministro Nilson Naves, Presidente. Ministro Edson Vidigal, Relator" (Publicado no DJ de 23.08.2004 - In RSTJ, 180/21)

Nessa mesma orientação, os julgados publicados na RSTJ, 181/31 e 182/49.

Preciso o magistério de Hely Lopes Meirelles, in Estudos e Pareceres de Direito Público, Revista dos Tribunais, São Paulo, 1991, v. 11, pp. 120/1, verbis:

"O equilíbrio econômico-financeiro é a relação que as partes estabelecem inicialmente no contrato administrativo, entre os encargos do particular e a retribuição devida pela entidade ou órgão contratante, para a justa remuneração do seu objeto (cf. nosso Licitação e Contrato Administrativo, ob. cito, p. 184)

Essa correlação encargo-remuneração deve ser conservada durante toda a execução do contrato, mesmo que alteradas as cláusulas de serviço, modificados projetos e programas, liberados trabalhos em quantidades inferiores às previstas, ou superados os prazos contratuais por mora da Administração, a fim de que se mantenha o equilíbrio econômico-financeiro, o qual, como bem observa Waline, é "direito fundamental de quem contrata com a Administração" (Marcel Waline. Droit Administratif, Paris, 1959, p. 574). Para De Soto, citado por Laubadère, "a manutenção desse equilíbrio constitui norma fundamental da teoria dos contratos administrativos. As obrigações das partes são tidas como calculadas de tal maneira que se equilibram do ponto de vista financeiro e o responsável pelo contrato deverá esforçar-se para manter, a qualquer custo, esse equilíbrio" (André De Laubadère, Contrats Administratifs, Paris, 1956, II/35, nota 6).

A\&C R. de Dir. Administrativo \& Constitucional, Belo Horizonte, ano 8, n. 33, p. 161-192, jul./set. 2008 
5. O reconhecimento do direito ao equilíbrio financeiro - o primeiro direito original do co-contratante com o Poder Público, segundo Péquignot (Théorie Générale du Contrat Administratif, Paris, 1945, p. 430) — surgiu como contrapartida ao poder-dever de alteração unilateral do contrato administrativo, mas vale também para os casos em que, impedido de invocar a exceção de contrato não cumprido, o particular contratado se vê obrigado a suportar o cumprimento irregular do ajuste ou a mora da Administração contratante.

Com efeito, o contrato administrativo, por parte da Administração, destina-se ao atendimento das necessidades públicas, mas, por parte do contratado. objetiva um lucro, através da remuneração consubstanciada nas cláusulas econômicas e financeiras. Esse lucro há que ser assegurado nos termos iniciais do ajuste porque, se de um lado a Administração tem o poder de modificar as condições de execução do contrato e de exigir a prestação da outra parte, ainda que ela mesma não tenha cumprido a sua, de outro lado, o particular contratado tem o direito de ver mantida a correlação encargo-remuneração estabelecida originariamente, uma vez que o seu objetivo ao participar da relação negocial foi - e continua sendo - o ganho pecuniário. Objetivo altamente lícito e respeitável, diga-se de passagem, que a Administração contratante não pode, validamente, restringir, exigindo que, a partir de um dado momento, a execução do contrato prossiga em condições menos lucrativas e até mesmo prejudiciais ao contratado, sem qualquer culpa deste.

6. Para a cabal satisfação desse direito, é forçoso se operem os necessários ajustes econômicos sempre que, por ato ou fato da Administração, for rompido o equilíbrio econômico-financeiro, em detrimento do particular contratado, independentemente de previsão contratual, como nos ensina Laubadère, nestes precisos termos: "Cette règle d'equilibre est quelque fois considerée comme résultant de la commune intention des parties; elle s'applique, en tous cas, même lorsqu'elle ne figure pas expressément dans le contrat" (André de Laubadère, Traité Élémentaire de Droit Administratif, Paris, 1957, p. 431. No mesmo sentido: Caio Tácito, Direito Administrativo, São Paulo, 1975, p. 293).

7. Por outro lado, se o respeito ao equilíbrio econômico-financeiro inicial, na hipótese de alteração unilateral do ajuste, constitui dever da Administração contratante; com muito mais razão é direito daquele e dever desta, nos casos em que o órgão ou entidade contratante abusa de sua posição privilegiada para descumprir ou cumprir irregularmente suas prestações, ou ainda suspender os prazos contratuais, obrigando o particular a suportar encargos excessivos, os quais, por não terem sido cogitados quando da elaboração da proposta ou da celebração do contrato, representam insuportáveis prejuízos, mormente numa conjuntura em que o custo do dinheiro é altíssimo e a inflação avilta a moeda a cada dia."

Da mesma forma, a lição de Celso Antônio Bandeira de Mello, in Revista Trimestral de Direito Público, v. 38/143-4, verbis:

“6. A legislação brasileira, a começar da Constituição, proclama a intangibilidade do equilíbrio econômico-financeiro original do contrato. Deveras o art. 37, XXI, da Lei Magna dispõe que “(...) obras, serviços. , compras e alienações serão contratados, mediante processo de licitação pública que assegure igualdade de condições a todos os concorrentes, com cláusulas que estabeleçam obrigações de pagamento mantidas as condições efetivas da proposta (...)”.

A\&C R. de Dir. Administrativo \& Constitucional, Belo Horizonte, ano 8, n. 33, p. 161-192, jul./set. 2008 
O versículo em apreço, como consta de sua dicção, estabeleceu uma correspondência entre as obrigações de pagamento e as condições efetivas da proposta. Dado que as partes se obrigarão em face daquelas condições efetivas, os pagamentos devidos ao contratado haverão de correlacionar-se às bases do negócio, uma vez que presidiram a oferta e se substanciaram em sua real compostura. Assim, tais pagamentos, para atenderem à previsão constitucional, necessitam resguardar a correlação estratificada sobre as condições efetivas em vista das quais se assentaram as partes, o que equivale a dizer que terão que ser reequilibrados se houver supervenientes desconcertos.

É, dessarte, no próprio texto constitucional que se assenta o resguardo daquilo que, em direito administrativo, é denominado "equilíbrio econômico-financeiro do contrato administrativo", com os decorrentes reajustes e revisões.

7. A nível infraconstitucional, o equilíbrio econômico-financeiro também se encontra enfatizado pelo direito positivo. Desde logo, a Lei 8.666, de 21.6.1993, que veicula regras gerais sobre licitação e contratos, consagra sua incolumidade em numerosas passagens. Basta referir as disposições que se estampam no art. $5^{\circ}, \S 1^{\circ}$; no art. $7^{\circ}, \S 7^{\circ}$; no art. 40 , XI e XIV, c; no art. $57, \S 1^{\circ}$; no art. $58, \S \S 1^{\circ}$ e $2^{\circ}$; e $65, \mathrm{II}, \mathrm{d}$, assim como em seu $\S 5^{\circ}$.

É certo, além disto, que a Lei de Concessões, Lei 8.987, de 13.2.1995, também encarece a proteção a equação econômico-financeira e exige-lhe a persistência ao longo da relação instaurada. Com efeito, seu art. $9^{\circ}$ estatui que a tarifa do serviço concedido "será preservada pelas regras de revisão".

O mesmo intuito de preservação do equilíbrio estipulado de início reaparece estampadamente nos $\S \S 2^{\circ}, 3^{\circ}$ e $4^{\circ}$ do mesmo artigo, ao estabelecerem, respectivamente, que: "Os contratos poderão estabelecer mecanismos de revisão das tarifas, a fim de manter-se o equilíbrio econômico e financeiro"; que: "Ressalvados os impostos sobre a renda. a criação, alteração ou extinção de quaisquer tributos ou encargos legais, após a apresentação da proposta, quando comprovado seu impacto, implicará a revisão da tarifa para mais ou para menos, conforme o caso" e que: "Em havendo alteração unilateral do contrato que afete o seu inicial equilíbrio econômico-financeiro, o poder concedente deverá restabelecê-lo, concomitantemente à alteração”.

$\mathrm{O}$ art. 18 da mesma lei dispõe que: "O edital de licitação será elaborado pelo poder concedente, observados, no que couber, os critérios e as normas gerais da legislação própria sobre licitações e contratos e conterá, especialmente: (...) VIII - os critérios de reajuste e revisão das tarifas".

O art. 23, entre as cláusulas categorizadas como essenciais ao contrato de concessão, em seu inciso IV, inclui as relativas, "ao preço do serviço e aos critérios e procedimentos para o reajuste e a revisão das tarifas”.

É inquestionável, pois, que a legislação de concessão de serviços públicos, tanto como a de contratos administrativos em geral - e os princípios gerais destes se aplicam às licitações para concessão de serviços públicos, como o declara seu art. 18 - consagram insistentemente a garantia do equilíbrio econômicofinanceiro, tanto pelo instituto da revisão, quanto dos reajustes.

Tudo isto está a revelar, inobjetavelmente, a decidida orientação legislativa de assegurar o equilíbrio econômico-financeiro do contrato administrativo.

No que concerne às limitações que sofre a Administração Pública para promover

A\&C R. de Dir. Administrativo \& Constitucional, Belo Horizonte, ano 8, n. 33, p. 161-192, jul./set. 2008 
alterações unilaterais no contrato administrativo, notadamente o contrato de concessão do serviço público, averba André de Laubadère, em seu já clássico Traité des Contrats Administratifs, 2a edição, L.G.D.J., Paris, 1984, t. 2º p. 406, n. 1177, verbis:

"D'une part, l'administration et son cocontractant ont conclu un certain contrat, ayant un certain objet: l'administration ne peut prétendre imposer une modification qui aboutirait à dénaturer le contrat, à lui donner en fait un objet nouveau, différent de celui qui a été envisagé dans la commune intention des parties; D'autre part, le cocontractant a conclu le contrat en considération de certaines conditions, notamment de ses possibilités techniques et financières. Ladministration ne peut prétendre imposer des modifications qui aboutiraient par leur importance à un bouleversement du contrat et de son économie générale".

Nesse sentido, ainda, os seguintes autores: Jean de Soto, in Droit Administratif - Theorie Generale du Service Public, Éditions Montchrestien, Paris, 1981, p. 339; Marcel Waline, in Traité Élémentaire de Droit Administratif, $6^{\mathrm{a}}$ ed., Libr. du Recueil Sirey, Paris, 1952, 392/3, §3; Jean Rivero, in Droit Administratif, $8^{\mathrm{a}}$ ed., Dalloz, Paris, 1977, pp. 454/5, no 481; Jacqueline MorandDeviller, in Cours de Droit Administratif, $3^{\text {a }}$ ed., Montchrestien, Paris, p. 362, "C"; Georges Dupuis, Marie J. Guédon, Patrice Chrétien, in Droit Administratif, $7^{\mathrm{a}}$ ed., Armand Colin, Paris, p. 403, "B”; Laurent Richer, in Droit des Contrats Administratifs, L.G.D.J., Paris, 1995, p. 198; Gaston Jèze, in Les Principes Généraux Du Droit Administratif - Théorie Générale Des Contrats De L'Administration, Troisième Partie, L.G.D.J., Paris, 1936, 1.142.

Em palavras lapidares, a propósito do alcance da garantia do equilíbrio econômico-financeiro do contrato administrativo, anotam Nicola Assini e Lucio Marotta, in La Concessione di Opere Pubbliche, CEDAM-PADOVA, 1981, pp. 73/4, verbis:

"È un principio pacifico che la gestione sia svolta dal concessionario a suo rischio e periculo. Ma è altrettanto evidente che rischi e pericoli sono a carico del concessionario solo in condizioni di normale svolgimento del rapporto economico regolato fra le parti dalla convenzione accessiva all'atto di concessione.

Fra le obbligazioni de concedente e quelle des concessionario si stabilisce all'inizio un certo rapporto ed è questo rapporto che deve essere mantenuto nel tempo, anche se ciò dovesse richiedere un mutamento delle obbligazioni assunte originariamente dalle parti.

Interessato particolarmente al mantenimento di questo rapporto è naturalmente il concessionario, che eviterà cosí di doversi accollare i rischi di gestione dipendenti da avvenimenti eccezionali ed imprevedibili. Ma anche il concedente ha interesse che il concessionario non venga mai a trovarsi in crisi in dipendenza di fatti che non gli siano addebitabili, poiché altrimenti verrebbe pregiudicato il perseguimento del fine pubblico che l'atto di concessione si riprometteva.

È nella logica della concessione che gli interessi delle parti non debbano risentire di quella contrapposizione o antiteticità che normalmente si verifica in qualsiasi altro rapporto obbligatorio scaturente da contratto. Concedente e concessionario sono in effetti legati da un rapporto del tutto peculiare, per cui essi vengono a trovarsi, secondo una plastica espressione, nella stessa barca."

Essa interpretação resulta do texto da Lei Maior, nos arts. 37, XXI, e 175, III,

A\&C R. de Dir. Administrativo \& Constitucional, Belo Horizonte, ano 8, n. 33, p. 161-192, jul./set. 2008 
da CF/88, que garante ao concessionário do serviço público a justa remuneração pela prestação do serviço, o que se verifica por meio da tarifa.

Ora, permitir que o Poder Público, por ato unilateral, alterasse o valor da tarifa, reduzindo-o, seria infringir o intento constitucional, comprometendo o equilíbrio econômico-financeiro do contrato de concessão, com repercussões negativas na prestação do serviço público e no próprio desdobramento do contrato, pondo em risco a continuidade e a regularidade da prestação do serviço.

Impõe-se, aqui, recordar as palavras de Sutherland, a propósito da interpretação das cláusulas constitucionais, verbis:

"No Court is authorized to so construe a clause of the constitution as to defeat its obvious ends, when another construction, equally accordant with the words and sense, will enforce and protect those ends. (...) a Court has no right to insert anything in the constitution which is not expressed and cannot fairly be implied, and when the text of a constitutional provision is not ambiguous, the courts are not at liberty to search for its meaning beyond the instrument itself." (William A. Sutherland, in Notes on the Constitution of the United States, Bancroft-Whitney Company, San Francisco, 1904, pp. 28/9) Benignius leges interpretandae sunt, quo voluntas eorum conservetur. (Celso, Dig. 1, 3, 18).

Ademais, como sabido, os atos e contratos praticados pelo Poder Público, sua validade, extensão e eficácia, somente poderão ser apreciados à luz das regras de direito público, notadamente o princípio da legalidade, hoje insculpido no art. 37 da CF/88.

A respeito, bem lembrou Hartmut Maurer, verbis:

"Le problème principal du contrat administratif, du point de vue juridique, est le principe de la soumission de l'administration à la loi et au droit (Gesetzmässigkeit der Verwaltung). Alors que le droit civil est marqué par le principe d'autonomie des relations entre personnes privées (Privatautonomie) et que, par suite, il est axé précisément sur le contrat, considéré comme moyen d'aménagement des rapports entre individus (Gestaltungsmittel), le droit administratif est dominé par le principe de légalité. Les règles juridiques s'imposant à l'administration régissent de plus en plus étroitement les rapports qu'elle a avec le citoyen, comme le montre l'extension du domaine réservé à la loi, la soumission croissante du pouvoir discrétionnaire à des règles de droit, la reconnaissance de droits subjectifs et le développment de la protection juridictionelle." (In Droit Administratif Allemand, traduit par M. Fromont, L.G.D.J., Paris, 1994, pp. 378/9, n. 25, “c” ). Por esses motivos, conheço do agravo regimental, negando-lhe provimento. É o meu voto. ${ }^{2}$

A respeito, destaca o saudoso Professor J. H. Meirelles Teixeira, verbis:

Uma vez efetuada a concessão, o Poder Público se acha vinculado às suas cláusulas com a mesma fôrça, o mesmo vigor e a mesma obrigatoriedade que o concessionário; assim como êste não pode faltar impunemente ao estipulado,

2 Revista do TRF/4a Região, n. 57, p. 143-152.

A\&C R. de Dir. Administrativo \& Constitucional, Belo Horizonte, ano 8, n. 33, p. 161-192, jul./set. 2008 
aquêle não poderá, sob pretexto da sua qualidade, subtrair-se ao exato cumprimento das obrigações e compromissos assumidos no ato da concessão. A concessão, representada pelo complexo das suas vantagens, se integra no patrimônio do concessionário, e qualquer ato da Administração, que importe em atentado contra a sua integridade, resultará para êle no direito de se reintegrar à custa do patrimônio coletivo.

A concessão é, portanto, o que os americanos chamam property (Abott, Municipal Corporation, vol. II, §751; Dillon, Municipal Corporation, vol. III), isto é, um direito incorporado no patrimônio do concessionário, e que não é lícito ao poder público revogar, anular, diminuir ou alterar, na qualidade, que é a sua, de direito adquirido pelo concessionário, a saber, integrado no conjunto ou no complexo de valores, protegidos pelo direito, e que constituem o seu patrimônio. ${ }^{3}$

\section{Da mesma forma, o Mestre Pontes de Miranda, verbis:}

A fixação e a revisão de tarifas segundo critério que se estabeleceu negocialmente sómente podem ser alteradas de acôrdo com as cláusulas do negócio jurídico, isto é, segundo critério negocialmente estabelecido. Qualquer lei federal, estadual ou municipal não pode ofender o direito adquirido, ato jurídico perfeito ou a coisa julgada (Constituição de 1946, art. 141, §3º), nem o princípio de isonomia ou de igualdade perante a lei (Constituição de 1946, art. $141, \S 1^{\circ}$ ), nem se afastar do art. 146 da Constituição de 1946, sedes materiae. ${ }^{4}$

Nesse sentido, voto que emiti na qualidade de relator dos Embargos de Declaração no AI no 2006.04.00.001762-2/PR, verbis:

Com efeito, em face do disposto no art. $5^{\circ}$, XXXVI, da CF/88, é indubitável que o contrato válido entre as partes constitui ato jurídico perfeito, protegido pelo texto constitucional, dele irradiando, para uma ou para ambas as partes, direitos adquiridos, não podendo ser alcançado por lei superveniente à data da celebração do contrato, mesmo quanto aos efeitos futuros decorrentes do ajuste negocial.

Nesse sentido, é de referir-se o ensinamento clássico de Julien Bonnecase, ao atualizar a obra de Baudry-Lacantinerie, verbis: "Les droits dérivant d'une convention expresse ou légalement présumée constituent, dans le sens de notre matière, des droits acquis à l'abri de l'atteinte de toute loi nouvelle, alors même qu'ils ont pour objet de paiements à faire à des époques successives, qui ne viendraient à échéance que postérieurement à la promulgation de cette loi' (Baudry-Lacantinerie, in Traité Théorique et Pratique de Droit Civil Supplément par Julien Bonnecase, Librairie Recueil Sirey, Paris, 1925, t. $2^{\circ}$, p. 123).

\footnotetext{
3 TEIXEIRA, J. H. Meirelles. Parecer publicado na Revista de Direito Administrativo, v. 50, p. 422. Nesse sentido, ainda, do mesmo autor a clássica monografia $O$ problema das tarifas nos serviços públicos concedidos. São Paulo, 1941. p. 224 et seq.

4 MIRANDA, Pontes de. Questões forenses. Rio de Janeiro: Borsoi, 1958. t. IV, p. 401.
}

A\&C R. de Dir. Administrativo \& Constitucional, Belo Horizonte, ano 8, n. 33, p. 161-192, jul./set. 2008 
Nesse sentido, também, é a jurisprudência da Suprema Corte dos Estados Unidos ao julgar o 263 U.S. 125, verbis:

"The integrity of contracts-matter of high public concern - is guaranteed against action like that here disclosed by section 10, art. 1, of the federal Constitution, "No state shall $* * *$ pass any *** law impairing the obligation of contracts." It was beyond the competency of the Legislature to substitute an "indeterminate permit" of rights acquired under a very clear contract." (In The Supreme Court Reporter - November, 1923 - July, 1924, West Publishing Co., St. Paul, 1924, v. 44 , p. 86 )"

Essa, também, é a lição clara e precisa do saudoso jurista Francisco Campos, em seu Direito Administrativo, Livr. Freitas Bastos, Rio, 1958, v. II, p. 11, verbis:

"O que a Constituição assegura, portanto, ao determinar que o ato jurídico perfeito continuará a ser regido pela lei do tempo em que se consumou, é, precisamente, o efeito jurídico daquele ato, isto é, as transformações por ele operadas nas relações jurídicas que constituem o seu conteúdo, seja criando, seja modificando, transferindo ou extinguindo direito.

O que resulta do ato jurídico perfeito é, precisamente, a aquisição de um direito, — ou a pretensão fundada a uma prestação, ou a modificação ou a extinção de direito anterior a determinada prestação.

O ato jurídico perfeito é subtraído ao império da lei posterior precisamente para que não seja prejudicado pela sua aplicação o direito que emergiu daquele ato e que por seu intermédio se tornou adquirido ou se incorporou ao patrimônio do indivíduo."

Ademais, a Lei Estadual no 14.235/03, que "revogou" as cláusulas do contrato, teve a sua eficácia suspensa pelo Eg. STF quando do julgamento da ADIn $n^{\circ}$ 3.075-DF.

Em seu voto, disse o ilustre Ministro Gilmar Mendes, verbis:

"De qualquer sorte, quanto às alegações de violação aos princípios de proteção ao ato jurídico perfeito, ao direito adquirido e do devido processo legal, penso, ao menos em um juízo cautelar, que a revogação contratual exigida pelo ato impugnado afigura-se ofensiva ao princípio da segurança jurídica. Meu voto, portanto, é no sentido de se deferir a liminar para que seja suspensa a vigência e a eficácia do ato impugnado”.

Descumprindo tal decisão, o Chefe do Poder Executivo do Estado do Paraná edita o Decreto $\mathrm{n}^{\circ} 5.434 / 05$, que reproduz o comando do texto legal suspenso pelo Pretório Excelso, em clara violação ao princípio da Separação e Harmonia dos Poderes - art. $2^{\circ}$ da CF/88 - , exorbitando o poder regulamentar que lhe confere a Lei Maior.

Pertinente, in casu, relembrar as sábias palavras proferidas pelo Justice Louis Brandeis no julgamento do caso Myers v. United States pela Suprema Corte Americana, verbis: "The doctrine of the separation of powers was adopted by convention of 1787 not to promote efficiency but to preclude the exercise of arbitrary power. The purpose was not to avoid friction, but, by means of the inevitable friction incident to the distribution of the governmental powers among three departments, to save the people from autocracy." (In The Supreme Court Reporter, West Publishing Co., St. Paul, 1928, v. 47, p. 85).

A\&C R. de Dir. Administrativo \& Constitucional, Belo Horizonte, ano 8, n. 33, p. 161-192, jul./set. 2008 
A propósito do poder regulamentar, é sempre atual o magistério de Pimenta Bueno, o mais autorizado intérprete da Carta Imperial de 1824, que o considera abusivo nos seguintes casos, verbis:

“ $1^{\circ}$ ) em criar direitos, ou obrigações novas, não estabelecidas pela lei, porquanto seria uma inovação exorbitante de suas atribuições, uma usurpação do poder legislativo, que só poderá ser tolerada por câmaras desmoralizadas. Se assim não fora poderia o governo criar impostos, penas, ou deveres, que a lei não estabeleceu, teríamos dois legisladores, e o sistema constitucional seria uma verdadeira ilusão;

$2^{\circ}$ ) em ampliar, restringir ou modificar direitos ou obrigações, porquanto a faculdade lhe foi dada para que fizesse observar fielmente a lei, e não para introduzir mudança ou alteração alguma nela, para manter os direitos e obrigações como foram estabelecidos, e não para acrescentá-los ou diminuílos, para obedecer ao legislador, e não para sobrepor-se a ele;

$3^{\circ}$ ) em ordenar, ou proibir o que ela não ordena, ou não proíbe, porquanto dar-se-ia abuso igual ao que já notamos no antecedente número primeiro. E demais, o governo não tem autoridade alguma para suprir, por meio regulamentar, as lacunas da lei, e mormente do direito privado, pois que estas entidades não são simples detalhes, ou meios de execução. Se a matéria como princípio é objeto de lei, deve ser reservada ao legislador; se não é, então não há lacuna na lei, sim objeto de detalhe de execução;

$4^{\circ}$ ) em facultar, ou proibir, diversamente do que a lei estabelece, porquanto deixaria esta de ser qual fora decretada, passaria a ser diferente, quando a obrigação do governo é de ser em tudo e por tudo fiel e submisso à lei;

$5^{\circ}$ ) finalmente, em extinguir ou anular direitos ou obrigações, pois que um tal ato equivaleria à revogação da lei que os estabelecera ou reconhecera; seria um ato verdadeiramente atentatório." (In Direito Público Brasileiro e Análise da Constituição do Império, Rio de Janeiro, 1857, p. 237, no 326)

E mais adiante, conclui o ilustre Mestre, verbis:

"O governo não deve por título algum falsear a divisão dos poderes políticos, exceder suas próprias atribuições, ou usurpar o poder legislativo. Toda e qualquer irrupção fora destes limites é fatal, tanto às liberdades públicas, como ao próprio poder." (In Op. Cit., p. 237)

Realmente, o ordenamento jurídico brasileiro atribui ao regulamento unicamente o papel de regulamentar a lei, esclarecendo o seu comando normativo, porém, sempre, observando-a, estritamente, não podendo inovar, ampliar ou restringir direitos, sob pena de ilegalidade.

Nesse sentido, orienta-se a melhor doutrina, verbis:

“748. - Le règlement de police, parce qu'il est un règlement, est hiérarchiquement inférieur à la loi. Il ne peut aller, dans ses dispositions, à l' encontre des prescriptions législatives, s'il en existe sur tel ou tel point perticulier. (PAUL DUEZ et GUY DEBEYRE, in Traité de Droit Administratif, Librairie Dalloz, Paris, 1952, p. 514) LES LIMITES DU POUVOIR RÉGLEMENTAIRE. Elles sont toutes l'expression de la subordination de l' autorité règlementaire au législateur. Ont peut les classer ainsi: $1^{\circ}$ Obligation de respecter les lois dans leur lettre et dans leur esprit; $2^{\circ}$ Impossibilité d'interpréter la loi: ce pouvoir

A\&C R. de Dir. Administrativo \& Constitucional, Belo Horizonte, ano 8, n. 33, p. 161-192, jul./set. 2008 
n'appartient qu'au législateur et aux tribunnaux: CE (Sect.), 10 juin 1949, Baudouin. $3^{\circ}$ Impossibilité pour l'autorité administrative de prende l'initiative de diminuer par um règlement la liberté des citoyens si le législateur n'a pas posé au mains le principe d'une telle limitation; (...)." (MARCEL WALINE, in Traité Élémentaire de Droit Administratif, 6 ${ }^{\mathrm{a}}$ ed., Libr. Du Recueil Sirey, Paris, 1952, p. 41)

Essa é, igualmente, a jurisprudência da Suprema Corte, verbis:

"Resolução no 194/1970 do CONFEA - Exercício da Profissão de Engenharia, Agronomia e Arquitetura - Exigências ilegais.

Dada a inferioridade constitucional do regulamento em confronto com a lei, é evidente que aquele não pode alterar, seja ampliando, quer restringindo, os direitos e obrigações prescritos nesta. (...).” (RE n ${ }^{\circ}$ 81.532/BA, Rel. Min. CUNHA PEIXOTO, in RTJ 81/494).

A respeito, leciona Bernard Schwartz, in Commentary on the Constitution of the United States - The Rights of Property, the Macmillan Company, New York, 1965, pp. 2/3, verbis:

"The Constitution has been construed as a living instrument intended to vest in the nation whatever authority may be appropriate to meet the exigencies of almost two centuries of existence.

To regard the Constitution solely as a grant of governmental authority is, nevertheless, to obtain but a partial and distorted view. Just as important is its function as a limitation upon such authority. As already emphasized in section 1, the American conception of a constitution is one which is not confined to viewing such instrument as a charter from which government derives the powers which enable it to function effectively. Instead, with us, the organic document is one under which governmental powers are both conferred and circumscribed.

The Constitution is thus more than a framework of government; it establishes and guarantees rights which it places beyond political abridgment. In this country, written constitutions were deemed essential to protect the rights and liberties of the people against the encroachments of governmental power."

Da mesma forma, impõe-se recordar a velha mas sempre nova lição de John Randolph Tucker, em seu clássico comentário à Constituição norteamericana, verbis:

"All acts of every department of government, within the constitutional bounds of powers, are valid; all beyond bounds are "irritum et insane" - null and void. Government, therefore, has no inherent authority, but only such as is delegated to it by its sovereign principal. Government may transcend the limits of this authority, but its act is none the less void. It cannot, by usurpation, jurally enlarge its powers, nor by construction stretch them beyond the prescribed limits." (In The Constitution of the United States, Callaghan \& Co., Chicago, 1899, pp. 66/7, §54).

Outro não é o ensinamento de Daniel Webster, verbis:

"The Constitution, again, is founded on compromise, and the most perfect and absolute good faith, in regard to every stipulation of this kind contained in it is indispensable to its preservation. Every attempt to grasp that which is regarded as an immediate good, in violation of these stipulations, is full of

A\&C R. de Dir. Administrativo \& Constitucional, Belo Horizonte, ano 8, n. 33, p. 161-192, jul./set. 2008 
danger to the whole Constitution." (In The Works of Daniel Webster, Little, Brown and Company, Boston, 1853, v. I, p. 331)

É manifesta, pois, a ilegalidade do Decreto Estadual $n^{\circ} 5.434 / 05$, eis que descumpriu decisão proferida pelo Eg. STF e, a pretexto de revogar ato que entende ilegal, na forma da Súmula 473 daquela Corte, em realidade violou a letra e o espírito desse enunciado, invadindo, no caso, a seara do Poder Judiciário.

A respeito, preciso o magistério de Francisco Campos, em seu Direito Administrativo, Imprensa Nacional, Rio, 1943, ao assinalar os limites da Administração Pública acerca da revogação dos atos administrativos, verbis: "Em princípio, os atos administrativos, particularmente aqueles de que resulta uma situação individual, não podem ser revogados pela própria administração. Este princípio se funda no fato de que a atividade administrativa é, igualmente, uma atividade jurídica, de que os seus atos não são atos quaisquer, mas atos juridicamente qualificados ou de relevância jurídica, sendo, como é, a administração uma das formas de execução do direito. Quando, portanto, o ato administrativo se resume em uma individuação da norma, a decisão do poder administrativo é assimilável à decisão do Poder Judiciário, adquirindo, assim, a força de ligar a administração ao seu próprio ato, o qual, em relação a ela, constitui uma res judicata. (...) Ora, não é da natureza da administração resolver contestações entre interesses que se opõem, havendo, como há, um departamento do governo especialmente designado, pela sua competência, para o exercício de tais funções. À administração, nos regimes em que não lhe cabe exercer funções contenciosas, falece competência para decidir sobre contestações emergentes da sua atividade, que se tem por completa e acabada com a emanação dos atos administrativos compreendidos na sua competência própria e específica." (In Op. Cit., pp. 60/1).

Nesse sentido tem decidido a Suprema Corte dos Estados Unidos.

Em Stone v. United States, tratava-se da venda de terras de domínio público tendo o Secretário do Interior, que era a autoridade competente para expedir os títulos de propriedade, alienado terras não incluídas entre aquelas cuja venda a lei autorizava. O seu sucessor na Secretaria do Interior promoveu a anulação da venda assim realizada. Instada a se pronunciar, a Suprema Corte deliberou que, embora nulo o ato, não caberia à administração rescindi-lo, eis que a rescisão constitui ato de natureza jurisdicional, que se inclui na competência do Poder Judiciário.

O princípio firmado nesse julgamento foi mantido no caso Beley et al. v. Naphtaly, julgado em 28 de fevereiro de 1898, oportunidade em que o Justice Peckham afirmou, verbis: "The case of U.S. v. Stone, 2 Wall. 525, has no bearing adverse to this proposition. In that case it was stated that a patent is but evidence of a grant, and the officer who issues it acts ministerially, and not judicially; that, if he issues a patent for land reserved from sale for law, such patent is void for want of authority, but that one officer of the land office is not competent to cancel or annul the act of his predecessor; that is a judicial act, and requires the judgment of a Court." (In The Supreme Court Reporter, West Publishing Co., St. Paul, 1899, v. 18, p. 358).

Da mesma forma, decidiu aquela Alta Corte no caso Michigan Land \& Lumber Co., Limited, v. Rust, julgado em 13 de dezembro de 1897 (In Op. Cit., p. 208).

A\&C R. de Dir. Administrativo \& Constitucional, Belo Horizonte, ano 8, n. 33, p. 161-192, jul./set. 2008 
Ora, no caso dos autos não há sequer falar na imprevisão contratual, pois a teoria da imprevisão consiste no reconhecimento de que eventos novos, imprevistos e imprevisíveis pelas partes, e a elas não imputáveis, refletindo sobre a economia ou a execução do contrato, autorizam a sua revisão, para ajustá-lo às circunstâncias supervenientes. Trata-se da aplicação da cláusula rebus sic stantibus, elaborada pelos pós-glosadores, que esposa a idéia de que todos os contratos dependentes de prestações futuras incluíam cláusula tácita de resolução, se as condições vigentes se alterassem profundamente.

Tal idéia se inspirava num princípio de eqüidade, pois se o futuro trouxesse um agravamento excessivo da prestação de uma das partes, estabelecendo profunda desproporção com a prestação da outra parte, seria injusto manterse a convenção, já que haveria indevido enriquecimento de um e conseqüente empobrecimento do outro (Cfe. sobre o tema os seguintes autores: ANDREA TORRENTE, Manuale Di Diritto Privato. 6a ed., Giuffrè Editore, 1965, pp. 447-50, §311; GILBERT MADRAY, Des Contrats D’après la Récent Codification Privée Faite aux États-Unis - Étude Comparée de Droit Américain et de Droit Français, Libr. Générale, Paris, 1936, p. 194; GEORGES RIPERT, La Règle Morale dans les Obligations Civiles, 4ª ed., Libr. Générale, Paris, 1949, p. 143 e ss.; PAUL DURAND, Le Droit des Obligations dans les Jurisprudences Française et Belge, Libr. Du Recueil Sirey, Paris, 1929, p. 134 e ss; VIRGILE VENIAMIN, Essais sur les Donnes Economiques dans L'Obligation Civile, Libr. Générale, Paris, 1931, p. 373 e ss.; MARCEL PLANIOL, Traité Élémentaire de Droit Civil, $10^{\mathrm{a}}$ ed, Libr. Générale, Paris, 1926, t. II, n. 1.168, p. 414; OTHON SIDOU, A Revisão Judicial dos Contratos, $2^{\mathrm{a}}$ ed., Forense, 1984, p. 95; PONTES DE MIRANDA, Tratado de Direito Privado, $3^{\mathrm{a}}$ ed., RT, 1984, t. XXV, §3.060, pp. 218-20 e, do mesmo autor, Dez Anos de Pareceres, Livr. Francisco Alves, Rio, 1976, vs. 7/36-9 e 10/197-9; ARNOLDO MEDEIROS DA FONSECA, Caso Fortuito e Teoria da Imprevisão, $3^{\mathrm{a}}$ ed., Forense, Rio, 1958, pp. 345-6, n. 242; FRANCISCO CAMPOS, Direito Civil - Pareceres, Livr. Freitas Bastos, 1956, pp. 05-11).

Todos os autores acima referidos admitem, sob os mais variados fundamentos doutrinários, a aplicação da teoria da imprevisão, mas apenas em circunstâncias excepcionais, ou seja, somente a álea econômica extraordinária e extracontratual, desequilibrando totalmente a equação econômica estabelecida pelos contraentes justifica a revisão do contrato com base na cláusula rebus sic stantibus.

Outro não é o entendimento adotado pela jurisprudência uniforme da Suprema Corte, em todas as oportunidades em que se manifestou sobre a tormentosa questão, como reflete o aresto relatado pelo eminente e saudoso Ministro ALIOMAR BALEEIRO, cuja cultura jurídica é por todos reconhecida, ao votar no RE no 71.443-RJ, verbis: "Rebus sic stantibus - Pagamento total prévio. 1. A cláusula rebus sic stantibus tem sido admitida como implícita somente em contratos com pagamentos periódicos sucessivos de ambas as partes ao longo de prazo dilatado, se ocorreu alteração profunda inteiramente imprevisível das circunstâncias existentes ao tempo da celebração do negócio..." (in RTJ 68/95. No mesmo sentido RTJ: 35/597; 44/341; 46/133; 51/187; 55/92; 57/44; 60/774; $61 / 682 ; 63 / 551 ; 66 / 561 ; 96 / 667 ; 100 / 140 ; 109 / 153 ; 110 / 328$ e $117 / 323)$.

No caso concreto, contudo, é de todo estranho aos princípios de justiça a aplicação da teoria da imprevisão, que deve ser aplicada com cautela pelo

A\&C R. de Dir. Administrativo \& Constitucional, Belo Horizonte, ano 8, n. 33, p. 161-192, jul./set. 2008 
magistrado, evitando que este interfira diretamente nos contratos celebrados, substituindo a vontade das partes, livremente pactuada, pela sua. A respeito, doutrina VIRGILE VENIAMIN, em clássica monografia, verbis: "En limitand ainsi l'application de la théorie de l'imprévision au cas où elle apparait comme une exigence, de l'harmonieux développement de l'organisation économique, on restreint par Là même consideráblement son étendue. En offrant au juge un critérium objectif, fondé sur les donnés concrètes dégagées grâce à une méthode d'observation directe, à l'aide du matériel préparé par des experts idoines, on évite l'arbitraite auquel la recherche d'une intention malveillante, toujours devinatoire peut fournir l'occasion. En outre, le rapprochement que nous venons de faire dans le présent chapitre, entre la lésion et l'imprévision - toutes les deux ayant le même caractère et répondant aux mêmes nécessités de l'ordre économique - nous indique une limitation technique du pouvoir de juge. Dans les deux cas, ce n'est pas à la révision du contrat qu'on doit aboutir, mais simplement à sa rescision (1). Il n'appartient point au juge d'orienter l'activité humaine en s'immiscant dans la teneur du contrat. Sa mission est terminée, dès qu'en obéissant aux directives économiques, il empêche la ruine de l'individu et lui assure en même temps que sa sauvegarde personnelle, une participation efficace à la collaboration générale" (In Essais sur les Données Economiques dans L'Obligation Civile, Libr. Générale, Paris, 1931, pp. 393-4). ${ }^{5}$

Ora, constitui princípio elementar da teoria geral dos contratos administrativos de que toda e qualquer modificação unilateral do contrato por parte do Poder Público que agrave os encargos do contratado obriga a Administração a compensar economicamente os novos encargos, restaurando-se, assim, o equilíbrio econômico-financeiro do ajuste.

Nesse sentido, dispõe o $\S 4^{\circ}$ do art. $9^{\circ}$ da Lei ${ }^{\circ}$ 8.987, de 13.02.1995, verbis:

Art. $9^{\circ}$.

(..)

$\S 4^{\circ}$ - Em havendo alteração unilateral do contrato que afete o seu inicial equilíbrio econômico-financeiro, o poder concedente deverá restabelecê-lo, concomitantemente à alteração.

É sabido o respeito pela observância das cláusulas dos contratos nos Estados Unidos da América, a tal ponto de constituir a integridade da relação contratual uma diretriz constitucional de primeira ordem, que deve ser preservada sempre que possível.

Quem o diz é o respeitado Professor Ernest Freund, em obra clássica,

\footnotetext{
${ }^{5}$ Revista do TRF/4a Região, n. 60, p. 169-176.
}

A\&C R. de Dir. Administrativo \& Constitucional, Belo Horizonte, ano 8, n. 33, p. 161-192, jul./set. 2008 
verbis: "The integrity of contractual obligation is a constitutional policy of the first order, and should be maintained wherever possible." 6

Questão que desperta considerável interesse e freqüente nos Tribunais é o exame pelas Cortes de Justiça da legalidade do ato de revisão das tarifas, bem como os seus limites.

A respeito, leciona Guimarães Menegale, verbis:

De fato, se a mais influente consideração que prevalece no processo de fixação das tarifas é o interêsse coletivo, é indisputável, também, que se deve atender ao interesse do concessionário, consagrado no princípio constitucional de justa retribuição do capital, resultante, em última análise, na proteção do interêsse geral pela circunstância de favorecer a eficiência do serviço concedido. Na apreciação, pelo Poder Judiciário, da legalidade do ato regulamentar da revisão das tarifas, o que tem de primar, por conseguinte, é a aplicabilidade do preceito constitucional. Ora, ao cotejar com a norma constitucional a legalidade do ato administrativo, não cabe ao Poder Judiciário discernir dados jurídicos e dados técnicos; uns e outros têm de condicionar-se à constitucionalidade da decisão. Parece indiscutível que, na hipótese da ilegalidade, ao juiz é facultado investigar se a ilegalidade proveio da elaboração dos elementos técnicos. ${ }^{7}$

E, adiante, acrescenta, verbis:

Em resumo: embora constitua tarefa de extrema delicadeza, o juiz poderá absterse de considerar se tal processo técnico utilizado na fixação ou revisão das tarifas é o mais aconselhável, mas, por certo, tem a faculdade de averiguar se da adoção de tais elementos técnicos resultou violação do princípio de justa retribuição ao capital. Os processos técnicos de fixação tarifária não têm o caráter de mistério que os torne indevassáveis à análise judicial; não fôra, por conseqüência, admissível, que, alegada a remuneração injusta do capital, e não surpreendida a ilegalidade formal do ato regulamentário, vedasse a administração pública ao juiz a investigação da causa intrínseca da injustiça na defeituosa aplicação da técnica, elementar na aplicação da lei, a pretexto, sobretudo, de que a justiça pode aquilatar "aplicação da lei”, e não de sua "boa ou má aplicação", pois a justiça não decide só se o poder administrativo "aplicou a lei”, mas se aplicou "bem ou mal". ${ }^{8}$

Em precioso estudo publicado na prestigiada Harvard Law Review, assinala Frederick K. Beutel, verbis:

The task of declaring that a commission has acted arbitrarily is not an easy one; many intangible elements may be present in the case which will lead the

\footnotetext{
6 FREUND, Ernest. Standarts of American Legislation. $2^{\text {nd }}$ ed. Chicago: The University of Chicago Press, 1965. p. 283.

7 MENEGALE, J. Guimarães. Parecer publicado na Revista Forense, v. 133, p. 52.

8 In: Op. cit., p. 52-53.
}

A\&C R. de Dir. Administrativo \& Constitucional, Belo Horizonte, ano 8, n. 33, p. 161-192, jul./set. 2008 
court to the conclusion that the commission has not given due and impartial consideration to all elements involved, and yet it may be extremely difficult for the court to place its finger upon the defect. (...) The Supreme Court is entirely conscious of the economic fact that any rate which reduces the utility's net return reduces its present value, which in business is simply a capitalization of its earning power. ${ }^{9}$

É conhecido o voto proferido pelo Justice Hughes no Minnesota Rate case, verbis: "The ascertainment of that value is not controlled by artificial rules. It is not a matter of formulas, but there must be a reasonable judgement, having its basis in a proper consideration of all relevant facts." ${ }^{10}$

\section{A reversão dos bens na concessão}

Nos termos da melhor doutrina, a reversão é o retorno do serviço ao poder concedente, expirado o prazo ajustado na concessão.

A reversão abrange apenas e tão-somente aqueles bens diretamente vinculados à prestação do serviço.

A respeito, claro o magistério de Carlos Medeiros da Silva, verbis:

12. A reversão tem por objeto permitir que o concedente, finda a concessão, possa continuar a exploração do serviço com os bens que, durante o seu curso, tenham sido adquiridos pelo concessionário, visando à execução do contrato. Êste acervo, utilizado pelo concessionário, no interêsse do serviço, não pode ser desfalcado, sob pena de impossibilitar ou dificultar a continuidade da exploração.

13. A reversão é, pois, um corolário, uma conseqüência da concessão. Findo o prazo da exploração concedida, os bens a ela vinculados ficariam sem utilização e na livre disposição do concessionário, caso não fôsse prevista a reversão. ${ }^{11}$

Da mesma forma, a lição de Hely Lopes Meirelles, verbis:

Reversão, como a própria palavra indica, é o retorno do serviço ao concedente, ao término do prazo contratual da concessão. Segundo a doutrina dominante, acolhida pelos nossos Tribunais, a reversão só abrange os bens, de qualquer natureza, vinculados à prestação do serviço. Os demais, não utilizados no objeto da concessão, constituem patrimônio privado do concessionário, que deles pode dispor livremente, e, ao final do contrato, não está obrigado a entregálos, sem pagamento, ao concedente. Assim é porque a reversão só atinge o serviço concedido e os bens que asseguram a sua adequada prestação. Se o

\footnotetext{
9 BEUTEL, Frederick K. Valuation as a Requirement of Due Process. Harvard Law Review, v. 43, p. 1267, 1929/ 1930. Nesse sentido, ainda, Gerard C. Henderson. Railway Valuation and the Courts. Harvard Law Review, v. 33, p. 910, 1919/1920.

10 In: The Supreme Court Reporter. St. Paul: West Publishing Co., 1913. v. 33, p. 754.

${ }^{11}$ Revista de Direito Administrativo, v. 43, p. 457-458.
}

A\&C R. de Dir. Administrativo \& Constitucional, Belo Horizonte, ano 8, n. 33, p. 161-192, jul./set. 2008 
concessionário, durante a vigência do contrato, formou um acervo à parte, embora provindo da empresa, mas desvinculado do serviço e sem emprego na sua execução, tais bens não lhe são acessórios, e, por isso, não o seguem necessariamente na reversão.

As cláusulas de reversão é que devem prever e tornar certo quais os bens que, ao término do contrato, serão transferidos ao concedente e em que condições. A reversão gratuita é a regra, por se presumir que, durante a exploração do serviço concedido, o concessionário retira não só a renda do capital, como também o próprio capital investido no empreendimento. Se nada for estipulado a respeito, entende-se que o concedente terá o direito de receber de volta o serviço com todo o acervo aplicado na sua prestação, sem qualquer pagamento. Mas casos há de concessão de curto prazo, ou de investimentos especiais e de alto custo, que justificam convencione-se a indenização total ou parcial dos bens da empresa, quando da reversão do serviço.

A reversão é, assim, a forma normal de extinção da concessão. As outras são formas excepcionais. ${ }^{12}$

Nesse sentido, precedente do Eg. STF ao julgar o RE $n^{\circ} 18.135$, rel. o eminente Ministro Orozimbo Nonato, verbis:

(...) $\mathrm{O}$ fato de ser a coisa destinada ao serviço público não faz com que o concessionário perca a sua propriedade. Por outro lado, é necessário que, ao fim do contrato, não haja qualquer hiato no serviço público desempenhado pelo concessionário. Essa a razão das cláusulas de reversão, cuja validade sempre se reconheceu. ${ }^{13}$

\section{Esclarecedora é a lição de Marcello Caetano, verbis:}

416. Propriedade do estabelecimento da concessão. Mas, enquanto durar a concessão do serviço público, a quem pertence a propriedade do respectivo estabelecimento quando tenha sido o concessionário a montá-lo e nos termos do acto de concessão deva vir a reverter para o concedente?

Há que distinguir duas hipóteses:

a) o estabelecimento do serviço constitui uma universalidade que a lei considera do domínio público;

b) os bens que constituem o estabelecimento do serviço são coisas meramente particulares.

Na hipótese a) o estabelecimento do serviço passa, desde o momento da sua criação, a ser propriedade pública, de que, portanto, será titular a pessoa colectiva de direito público que houver concedido o serviço.

\footnotetext{
12 MEIRELLES, Hely Lopes. Licitação e contrato administrativo. 9. ed. São Paulo: Revista dos Tribunais, 1990. p. 302-303. No mesmo sentido: BIELSA, Rafael. Derecho administrativo. Buenos Aires: El Ateneo, 1947. t. I, p. 422 et seq.

13 Revista Forense, v. 153, p. 127. No mesmo sentido, RE n 65.646-SP, rel. Min. Themístocles Cavalcanti, RTJ $47 / 688$.
}

A\&C R. de Dir. Administrativo \& Constitucional, Belo Horizonte, ano 8, n. 33, p. 161-192, jul./set. 2008 
Entende-se que o concessionário procedeu como se fora um empreiteiro que tivesse aceite um pagamento diferido da obra produzida. Esse pagamento obtém-no, por suas próprias mãos, do rendimento da exploração do serviço. E se o concedente resolver resgatar a concessão do serviço, terá então de fazer o pagamento imediato da parte do custo dos bens ainda não amortizada.

$\mathrm{Na}$ hipótese b) os bens são propriedade do concessionário enquanto durar a concessão. O concessionário apenas se obrigou para com o concedente a entregar-lhos gratuitamente se a concessão atingir o termo previsto. Trata-se, pois, da obrigação para o concessionário de fazer uma prestação de coisas ao concedente, se a concessão for mantida e as suas cláusulas observadas por este e quando o respectivo prazo de duração expirar (obrigação condicional e a termo).

Se não se verificar a condição, ou se o concedente quiser obter os bens antes do termo, terá de comprá-los pelo seu justo preço.

Portanto o concedente, nesta hipótese, tem apenas, relativamente aos bens e durante a concessão, um direito de crédito, mas não quaisquer direitos reais. ${ }^{14}$

Por conseguinte, os bens, móveis e imóveis, adquiridos pela concessionária constituem bens do patrimônio geral desta e não do patrimônio especial vinculado à destinação do serviço público objeto da concessão.

A respeito, exige-se expressa disposição acerca do tema debatido já no edital de convocação e no próprio contrato de concessão para prevenir dúvidas e questionamentos (arts. 18, X e XI, e 23, X, da Lei no 8.987/95).

Em 1907, ao julgar a questão referente à concessão obtida pela Cleveland Electric Railway Co. para explorar o serviço de transporte à tração elétrica nas ruas de Cleveland, deliberou a Suprema Corte dos Estados Unidos, verbis: "The title to the rails, poles, and other appliances for operating the Garden street branch of the Cleveland street railway system remaining in the various streets at the expiration of its franchise is in the railway company which has been operating the road." 15

Dessa forma, bens reversíveis são apenas aqueles diretamente vinculados ao objeto da concessão e que visam à continuidade da prestação do serviço público. É a lição de Gaston Jèze, verbis: "Tous les immeubles qui ne font pas retour au concédant restent la propriété du concessionnaire; ces immeubles portent, dans la pratique, le nom de domaine privé par opposition au domaine concédé." ${ }^{16}$

\footnotetext{
${ }^{14}$ CAETANO, Marcello. Manual de direito administrativo. 10. ed. 3. reimpr. Coimbra: Almedina, 1986. t. II, p. 1120-1121, n. 416.

15 In: The Supreme Court Reporter. St. Paul: West Publishing Co., 1907. v. 27, p. 202.

16 JĖZE, Gaston. Les Principes Généraux du Droit Administratif: Théorie Générale des Contrats de L'Administration. Troisième partie. 3è éd. Libr. Générale, 1936. p. 1184.
} 
Precisa e escorreita a conclusão do Professor Celso Antônio Bandeira de Mello, em alentado artigo de doutrina, quando afirma, verbis:

8. Nos casos em que deva existir reversão de bens, seja por força da expiração normal da concessão, seja em decorrência de sua extinção prematura, a necessidade de indenizar o concessionário pelos bens revertidos prende-se inteiramente ao fato de ter ou não havido amortização do capital neles substanciado.

Em geral são outorgadas por prazo longo as concessões em que os bens aplicados ao serviço devem, ao final, integrar-se no patrimônio público mediante reversão. Assim se faz para que os concessionários amortizem os investimentos efetuados, isto é, paguem-se destes dispêndios, ressarcindo-se através das próprias tarifas cobradas dos usuários, pela adscrição de uma parcela delas a tal finalidade. Dessarte, ao expirar-se a concessão por decurso do prazo, o Poder Público não incorrerá em desembolsos para assenhorear-se do acervo.

Com efeito, é claro que se o prazo fosse curto, a parcela tarifária comprometida neste propósito revelar-se-ia insuficiente para reposição do capital, a menos que se fixassem tarifas altíssimas. Ora, como o Poder Público deve zelar pala ampla acessibilidade do serviço aos usuários e garantir-lhes as condições mais convenientes, as tarifas precisam ser módicas. Segue-se que o prazo de tais concessões, conforme dito, haverá de ser longo. Então, graças à amplitude dele, adrede estabelecida para atender ao citado objetivo, presume-se que, ao se expirar normalmente o prazo fixado, já terá havido, salvo prova em contrário, amortização do capital investido pelo concessionário. Por esta razão, admitese, em princípio, que os bens aplicados ao serviço revertem ao concedente sem ônus para ele.

Este modelo, que é o usual, poderá, entretanto, sofrer algum desconcerto quando, em épocas já avizinhadas da consumação do prazo, o concessionário seja obrigado a efetuar investimentos suplementares, quer para manter a qualidade ou a atualização técnica do serviço, quer para expandi-lo ante o incremento da demanda dos usuários. Aí sim — e só aí — o tempo remanescente será insuficiente para permitir que as tarifas ao longo dele hauridas também atendam a finalidade apontada, irrompendo, pois, a necessidade de que o Poder Público, na reversão, acoberte o montante que restou insuprido.

9. É bem de ver, todavia, que se a concessão extinguir-se prematuramente, seja por encampação, seja por resgate, ficará convulsionado o supra referido esquema de amortização do capital.

Deveras, a antecipação do término do vínculo subverterá a expectativa sobre a qual estavam assentados os cálculos relativos ao acobertamento do capital. Donde, se os bens, com esta antecipação, viessem a ser absorvidos pelo concedente sem compensação econômica que cobrisse o remanescente de investimentos ainda não amortizados pelas percepções tarifárias passadas, o concessionário sofreria uma perda patrimonial. É dizer, ficaria injustamente agravado pela transferência gratuita de uma parcela de seus recursos para o Poder Público: aquela que em prol dele despendeu e não lhe foi reposta.

Donde, se ao findar-se a concessão o concessionário não houver amortizado integralmente o capital que investiu, mediante percepção das tarifas fixadas

A\&C R. de Dir. Administrativo \& Constitucional, Belo Horizonte, ano 8, n. 33, p. 161-192, jul./set. 2008 
pelo concedente e cobradas pelo concessionário dos usuários (mais eventuais subsídios que o Poder Público lhe haja aportado) é óbvio que o concedente, para capturar os bens aplicados ao serviço, terá de versar-lhe o quantum correspondente ao valor ainda pendente de amortização.

Tal pagamento, então, será de rigor, como contrapartida da assunção dos bens pelo Estado. Deveras, em situações deste jaez, o concessionário, ao invés de retirar-se com o acervo representativo de capital que aportou, deixa-o em mãos do concedente. Cumpre, pois, que seja acobertado quanto a isto. De resto, a ser de outro modo, ninguém em seu juízo perfeito, se abalançaria a engajar-se em vínculo de tal ordem. Seria, evidentemente, um negócio desastroso aquele em que alguém, aplicando recursos próprios para obter uma remuneração pelo investimento feito, ficasse, ao final, despojado total ou parcialmente do capital investido. Sairia, evidentemente, empobrecido se não houvesse podido sequer recuperá-lo ao cabo do empreendimento.

Note-se que aqui não está em pauta questão atinente a uma eventual compensação econômica pela perda dos proveitos (lucro ou remuneração do capital) que - não fora pelo encurtamento do prazo - seriam hauridos pelo concessionário com a cobrança das tarifas ao longo de todo o período em que estava titulado para captá-las. O de que se cuida neste passo, é, meramente, de reconhecer que se a extinção da concessão efetuar-se antes do prazo, não comparece o referido fundamento jurídico e econômico embasados da absorção gratuita do acervo pelo concedente, a título de reversão.

Como se viu, a amortização do capital é que se constitui na causa hábil para supedanear a absorção definitiva do acervo sem ônus para o concedente. Assim, ocorrendo extinção prematura da concessão e conseqüente reversão dos bens aplicados ao serviço, se não fosse versada ao concessionário a contrapartida pelos investimentos ainda descobertos, seguramente ocorreria injurídico apoderamento, pelo concedente, de uma parcela do patrimônio de sua contraparte. E isto, repita-se, tanto ocorrerá nos casos de encampação quanto nos de caducidade.

10. Aliás, tratando-se de encampação, isto é, encerramento suscitado por razões administrativas de mera conveniência ou oportunidade, portanto, sem que o concessionário haja praticado falta que a justificasse o Poder Público deverá indenizá-lo pela antecipação do encerramento do prazo ao longo do qual perceberia, através das tarifas, o proveito econômico em vista do qual travara o vínculo. Deveras, seu ingresso na relação jurídica fora motivado, evidentemente, pela expectativa de um ganho, que teria buscado em outro negócio (mobilizando para est'outro seu capital, aptidão empresarial, experiência e recursos), se não fora pelo liame que travou com o concedente, confiado em que, bem servindo, hauriria durante todo o prazo estipulado os proveitos do empreendimento.

Embora seja certo que o Poder Público possa, sem violar o direito, retomar o serviço dado em concessão, também é certo que deverá compor o prejuízo econômico dessarte causado. Além disto, como é óbvio, terá de acobertarlhes, a parte ainda não amortizada do capital, como já se viu. Nisto estará, pura e simplesmente, cumprindo o elementar dever de respeitar o capital alheio, ou seja, de não apropriar-se do que pertence a outrem.

A\&C R. de Dir. Administrativo \& Constitucional, Belo Horizonte, ano 8, n. 33, p. 161-192, jul./set. 2008 
11. Quando o encerramento prematuro do vínculo resultar de caducidade, vale dizer, extinção decidida pelo Poder Público como decorrência de faltas graves do concessionário que o fizeram incurso nesta sanção, é claro que a este não será devida qualquer indenização pela perda da exploração do serviço. Pelo contrário, o concessionário é que, em sua qualidade de inadimplente, além de responder pelas multas ou quaisquer outros agravamentos previstos (perda da caução efetuada, por exemplo), terá ainda de arcar com as perdas e danos que haja causado ao concedente pelo fato de havê-lo levado a promover o encerramento prematuro do vínculo.

Sem embargo, nem por isso o concedente poderia assenhorear-se gratuitamente dos bens constitutivos do acerto, se ainda não estiverem - como não deverão estar — integralmente amortizados. Fazê-lo, equivaleria a confiscar investimentos aportados pelo concessionário.

Não há confundir o tópico atinente à prestação do serviço, e, assim, portanto, o de sua persistência ou cancelamento prematuro, com o tópico relativo ao capital invertido pelo concessionário e que estará substanciado em bens que reverterão ou não para o concedente ao encerrar a relação jurídica.

A extinção antecipada do vínculo, por si mesma, nada predica com relação à reversão dos bens. Logo, a causa pela qual se antecipa a dissolução do vínculo (encampação ou caducidade) não poderia ser, por si mesma, nem determinante de tal conseqüência, nem determinante de onerosidade ou gratuidade de reversão. Em suma: por não existir ligação entre a causa de extinção prematura do vínculo e a reversão dos bens, também não existe ligação entre ela e o fato de dever-se efetuá-la com ou sem indenização.

12. Com efeito, nos casos em que a concessão não demande reversão dos bens, como poderia suceder em uma concessão de linhas de ônibus - conforme hipótese dantes figurada - provavelmente a ninguém acudiria supor que, em sendo decretada sua caducidade, o concessionário perderia os veículos ou equipamentos postos à disposição do serviço.

Por que não ocorreria tal suposição?

Simplesmente porque a reversão dos bens não é uma conseqüência da caducidade; não é uma sanção pela inadimplência do concessionário. Se o fosse, deveria operar - e sem ônus para o concedente - também nos casos em que não estava prevista (explícita ou implicitamente). Em rigor, nada tem a ver com ela. Donde, não haveria porque presumir que a gratuidade da reversão seja uma conseqüência natural da caducidade, nos casos em que dita reversão (quando pressuposta) vem a ser antecipada por força de prematura extinção do veículo suscitada por inadimplência do concessionário.

A reversão - cumpre repetir - não é sanção, mas um efeito que se processa com supedâneo em outros fundamentos e na conformidade de outros pressupostos, tudo conforme dantes exposto. Donde, ocorrerá apenas nos termos que a legitimam, isto é, com pleno acobertamento do capital invertido pelo prestador do serviço e nos casos em que é demandada para continuidade dele. Não haveria, então, porque imaginar que a gratuidade da reversão deva ser havida como uma resultante da caducidade.

13. Além disto, seria incabível apropriar-se deste remanescente de capital sem indenizá-lo, porquanto, com tal procedimento, haveria um confisco (o que é

A\&C R. de Dir. Administrativo \& Constitucional, Belo Horizonte, ano 8, n. 33, p. 161-192, jul./set. 2008 
constitucionalmente vedado) e um enriquecimento ilícito do concedente sobre o patrimônio alheio. Acresce, ainda, que sobre tratar-se de sanção violentíssima, sua aplicação, salvo previsão expressa em lei ou no próprio ato concessivo, resultaria absurda, porque extraída do nada.

Deveras, os poderes jurídico-administrativos ou resultam da lei ou dimanam de relações constituídas ex voluntate. Como se sabe, por força do princípio da legalidade (art. 37 da CF), a Administração, para impor algo a outrem, necessita estar embasada em lei (art. $5^{\circ}$, II, e 84, IV). Fora daí, somente se estiver calçada em disposição à qual sua contraparte tenha se submetido voluntariamente, como sucederia em relação a cláusulas de uma concessão ou a normas contratuais livremente acordadas entre os contraentes. Se a Administração não estiver embasada em lei que lhe autorize impor a sanção "a" ou "b", ou em cláusula da concessão, evidentemente carecerá de fundamento jurídico para impô-la. Logo, presumir, nos casos de caducidade da concessão, que a reversão prevista independe de indenização da parcela do capital ainda não amortizada é literalmente um absurdo. ${ }^{17}$

\section{Outro não é o ensinamento de Otto Mayer, verbis:}

Tous les moyens matériels et personnels qui jusque-là servaient à l'entreprise représentent maintenant entre ses mains une masse sans emploi. S'il ne se produit rien d'autre, il pourra en disposer librement.

La ci-devant propriété publique de la route, de la voie ferrée, du canal, est déclassée avec la cessation de la concession; les immeubles ainsi que les meubles corporels, les contrats de service, les baux en cours, tout ce qui reste de l'entreprise lui appartient.

Mai celui de qui émane la concession peut intervenir pour s'emparer de ces moyens, en tant qu'ils lui semblent nécessaires pour assurer la continuation de l'entreprise que l'intérêt public pourrait exiger. Celui qui se soumet au rapport de concession se soumet par là même à l'obligation de laisser au besoin dans l'entreprise tout ce qu'il y emploie. (...) Mais il est évident que l'ont impose ainsi à l'entrepreneur un sacrifice spécial; celui-ci aura donc, d'après les principes généraux, droit à une indemnité. Cette indemnité se calcule d'après la valeur qui lui est enlevée, non pas la valeur de ces choses en tant qu'elles étaient comprises dans l'entreprise, mais la valeur brute, celle qu'elles présenteraient pour l'entrepreneur s'il en avait disposé après l'extinction de l'entreprise. ${ }^{18}$

Ora, a reversão é cláusula do contrato de concessão, estando vinculada diretamente ao seu objeto, ou seja, à execução do serviço.

Assim, a reversão incide apenas sobre aqueles bens afetados ou destinados à exploração do serviço, pois, como bem destaca Themístocles Brandão Cavalcanti, reverter é fazer retornar ao poder concedente não o

17 Reversão dos bens na concessão. Revista Trimestral de Direito Público, v. 7, p. 10-13.

18 In: Le Droit Administratif Allemand. Édition française par l'auteur. Paris: M. Giard \& E. Brière, 1906. t. IV, p. 178-179.

A\&C R. de Dir. Administrativo \& Constitucional, Belo Horizonte, ano 8, n. 33, p. 161-192, jul./set. 2008 
material ou o patrimônio, mas o serviço, que deve estar em condições de continuar a funcionar. ${ }^{19}$

Como regra geral, segundo Laubadère, o contrato de concessão determina os bens que devem ficar com o poder concedente, deixando, às vezes, a este o direito de retomada desses bens.

Eis o seu magistério, verbis:

C'est en fait par une définition négative que l'on peut déterminer quels biens demeurent, en fin de concession, la propriété du concessionaire: comme on va le voir ci-dessous, le contrat détermine les biens qui reviennent au concédant, soit à titre de retour, soit à titre de reprise; par ailleurs il laissa parfois au concédant la simple faculté de reprendre ces biens. On peut donc dire que les biens qui demeurent la propriété du concessionaire sont d'une part ceux que le contrat ne fait pas figurer parmi les biens de retour ou de reprise, d'autre part ceux qui figurent parmi ces biens mais que le concédant s'abstient finalement de reprendre lorsque le contrat lui en laissait la faculté. (...) Les cahiers des charges considèrent en règle générale comme biens de retour ou de reprise les biens qui font partie intégrant de l'exploitation du service. ${ }^{20}$

\section{A encampação e a justa indenização ao concessionário}

Uma das modalidades de extinção da concessão de serviço público é a encampação, definida pela Lei ${ }^{\circ}$ 8.987/95 como "a retomada do serviço pelo poder concedente durante o prazo da concessão, por motivo de interesse público, mediante lei autorizativa específica e após prévio pagamento da indenização" (art. 37).

Questão importante a ser apreciada na encampação - e nesse particular não enfrentada expressamente pelo legislador - é quanto à forma do pagamento e o critério a ser utilizado na indenização.

A propósito, deliberou o Eg. STF quando do julgamento do RE $n^{\circ}$ 75.930-GO, relator o saudoso Ministro Rodrigues Alckmin, verbis: "Encampação. Fixação do valor dos bens da concessionária. (...). Legitimidade da aplicação das normas da desapropriação para fixar-se a indenização justa ..."21

Realmente, consoante acentua a melhor doutrina, considerando-se que a encampação extingue o contrato de concessão antes do prazo

\footnotetext{
19 CAVALCANTI, Themístocles B. Parecer publicado na Revista de Direito Administrativo, v. 102, p. 453-462. No mesmo sentido, MIRANDA, Pontes de. Op. cit., p. 316-317; CAMPOS, Francisco. Direito administrativo. Rio de Janeiro: Imprensa Nacional, 1943. p. 250-253; FALCÃO, Alcino Pinto. A Cláusula de Reversão na Concessão de Serviço Público. Revista de Direito Público, v. 15, p. 129-135.

${ }^{20}$ LAUBADÈRE, André de. Traité Des Contrats Administratifs. 2è ed. Paris: L.G.D.J., 1984. t. 2, p. 745, n. 1507.

${ }^{21}$ RTJ 68/540.
}

A\&C R. de Dir. Administrativo \& Constitucional, Belo Horizonte, ano 8, n. 33, p. 161-192, jul./set. 2008 
estipulado no ajuste, tem o concessionário direito à indenização, que deve compreender não somente a recomposição dos investimentos ainda não amortizados pela remuneração do concessionário como o próprio lucro que este deveria obter com a exploração do serviço concedido, ora extinto pela encampação, pelo prazo restante para o término do contrato. ${ }^{22}$

Preciso, no ponto, o magistério autorizado do Professor Celso Antônio Bandeira de Mello, verbis:

Nestes casos, por não haver o concessionário dado causa ao ato extintivo, faz jus à indenização pela antecipação do termo final da concessão. Note-se que tal sucede não porque o Poder Público seja inadimplente, uma vez que é direito seu extinguir a qualquer momento a concessão, mas porque a antecipação de seu encerramento, ao prazo previsto, repercute diretamente sobre a equação econômica-financeira, a qual, como é lógico, é calculada em função de certo lapso de tempo. Com efeito, a amortização paulatina do capital investido pelo concessionário e os lucros previstos ocorrem ao longo de uma dilação temporal. Daí que o Poder Público, devendo garantir o equilíbrio econômicofinanceiro, por ser de natureza contratual, encerrará a concessão quando queira, mas garantirá a "expressão econômica" que se realizaria ao longo de certo prazo: aquele tomado como referência de seu valor. Portanto, compensará as importâncias que deixarão de ser percebidas e o restante do capital não amortizado..$^{23}$

Nesse sentido, também, a lição do Mestre Enzo Silvestri, em monografia específica consagrada ao tema, verbis:

XIV. Quanto alla misura dell'indennità, si è detto già che essa deve essere adequata al sacrificio imposto al concessionario, deve rappresentare cioè l'effettivo equivalente del diritto sottratto. Nella determinazione dell'indennità deve quindi tenersi conto non soltanto del danno emergente, costituito dal valore degli impianti che passano al concedente, ma anche del lucro cessante, rappresentato dagli utili che vengono meno al concessionario in conseguenza dell'anticipata cessazione del rapporto. ${ }^{24}$

\footnotetext{
22 Nesse sentido, os seguintes autores: MEIRELLES, Hely Lopes. Estudos e pareceres de direito público. São Paulo: Revista dos Tribunais, 1986. v. 9, p. 217; ZANOBINI, Guido. Corso Di Diritto Amministrativo. $5^{a}$ ed. Milano: Dott. A. Giuffrè, 1957. v. 3, p. 398; LIMA, Ruy Cirne. Pareceres (Direito Público). Porto Alegre: Sulina, 1963. p. 171-186; BIELSA, Rafael. Op. cit., p. 422; JUSTEN FILHO, Marçal. Teoria geral das Concessões de Serviço Público. 2. reimpressão. São Paulo: Dialética, 2007. p. 586-588.

23 BANDEIRA DE MELLO, Celso A. Prestação de serviços públicos e administração indireta. 2. ed. 3. tiragem. São Paulo: Revista dos Tribunais, 1987. p. 51. Da mesma forma, ZANOBINI, Guido. Op. cit., p. 397; BOSC, A. La Théorie de L'Imprévision. Revue Du Droit Public, Paris, XXXIIIe année, p. 419-420, 1926; BALEEIRO, Aliomar. Parecer publicado na Revista Forense, v. 197, p. 51-76.

24 SILVESTRI, Enzo. // Riscatto Delle Concessioni Amministrative. Milano: Dott. A. Giuffrè, 1956. p. 275. Do mesmo autor, "Concessione", publicado na Enciclopedia Del Diritto. Milano: Giuffrè Editore, 1961. v. 8, p. 385. Nesse sentido, ainda, VITTA, Cino. Concessioni (Diritto Amministrativo). In: Novissimo Digesto Italiano. UTET, 1964. v. III, p. 927.
}

A\&C R. de Dir. Administrativo \& Constitucional, Belo Horizonte, ano 8, n. 33, p. 161-192, jul./set. 2008 
Ao julgar o caso Smyth v. Ames, em 1898, deliberou a Suprema Corte dos Estados Unidos, verbis:

If a railroad company has bonded its property for an amount that exceeds its fair value, or if its capitalization is largely fictitious, it may not impose upon the public the burden of all increased rates, necessary to realize profits on this fictitious capitalization; but the basis of all calculations as to the reasonableness of rates must be the fair value of the property used by the company for the convenience of the public. In ascertaining this value, the original cost of construction, the amount expended in permanent improvements, the amount and market value of its bonds and stock, the present as compared with the original cost of construction, the probable earning capacity of the property under particular rates prescribed by statute, and the sum required to meet operating expenses, are all matters for consideration, and are to be given such weight as may be just and right in each case. ${ }^{25}$

Nesse sentido, ainda, voltou a Corte Suprema a apreciar a questão no Hope Case, em 1944, traçando as seguintes diretrizes, verbis:

The rate-making process under the Act, i.e., the fixing of "just and reasonable" rates, involves a balancing of the investor and the consumer interests. Thus we stated in the Natural Gas Pipeline Co. case that "regulation does not insure that the business shall produce net revenues." 315 U.S. at page 590. 62 S.Ct. at page 745,86 L.Ed. 1037. But such considerations aside, the investor interest has a legitimate concern with the financial integrity of the company whose rates are being regulated. From the investor or company point of view it is important that there be enough revenue not only for operating expenses but also for the capital costs of the business. These include service on the debt and dividends on the stock. Cf. Chicago \& Grand Trunk R. Co. v. Wellman, 143 U.S. 339. 345, 346, 12 S. Ct. 400, 402, 36 L.Ed. 176. By that standard the return to the equity owner should be commensurate with returns on investments in other enterprises having corresponding risks. That return, moreover, should be sufficient to assure confidence in the financial integrity of the enterprise, so as to maintain its credit and to attract capital. ${ }^{26}$

\section{Conclusão}

Ante tudo o que foi exposto, infere-se, resumidamente:

$1^{\circ}$ ) Incumbe ao concessionário manter o regular funcionamento do serviço público concedido e ao Poder Público, na qualidade de titular do

\footnotetext{
25 In: The Supreme Court Reporter. St. Paul: West Publishing Co., 1899. v. 18, p. 418. Nesse sentido, ainda, consultar John Bauer and Nathaniel Gold, Public Utility Valuation for Purposes of Rate Control. New York: The Macmillan Company, 1934. p. 21-24; e MAYER, Otto. Op. cit., p. 183.

26320 U.S. 591 - Federal Power Commission v. Hope Natural Gas Co., in The Supreme Court Reporter. St. Paul: West Publishing Co., 1944. v. 64, p. 288. Nesse sentido, também, 315 U.S. 575 - Federal Power Commision $v$. Natural Gas Pipeline of America, in The Supreme Court Reporter. St. Paul: West Publishing Co., 1942. v. 62, p. 744-745.
}

A\&C R. de Dir. Administrativo \& Constitucional, Belo Horizonte, ano 8, n. 33, p. 161-192, jul./set. 2008 
poder concedente, velar por fornecer ao concessionário os meios legais e econômicos visando a atingir esse objetivo.

Por outro lado, rompida a equação econômico-financeira da concessão, urge o seu pronto restabelecimento assegurando-se, assim, a regular e contínua prestação do serviço público concedido.

Ao fixar-se a tarifa impõe-se que se considere a depreciação da moeda e, via de conseqüência, a reavaliação do ativo visando a incentivar o emprego de capitais privados nas empresas concessionárias de serviço público.

A respeito, pertinente a lição do eminente Ministro Themístocles Brandão Cavalcanti, verbis:

Há, neste processo de fixação de tarifas, nesta arbitragem entre dois interêsses em jôgo, um problema técnico, cujo desconhecimento é inadmissível, mas também um sentido ético, sem cujo respeito, ineficaz e contraproducente será a ação da Administração pública, como conciliadora e homologadora de interêsses.

Eis porque, essa tarefa tem sido atribuída a comissões idôneas, moral e técnicamente, que devem trabalhar sob o regime da maior publicidade, de portas abertas, dando contas públicas de seu trabalho, porque o consumidor, o usuário, tem o direito de saber porque vai pagar o quantum fixado. ${ }^{27}$

Quando do julgamento do West et al. v. Chesapeake \& Potomac Thelefone Co. of Baltimore City case, deliberou a Suprema Corte Americana, verbis:

Just valuation of utilities for rate purposes must take into account and give proper weight to prices trends, changes in level of prices, amount of investment, appraisal of present value, actual cost, reproduction cost, and other elements affecting value.

Public service corporation ought not, in rate proceedings, to be permitted to claim to the last dollar an increased value consequent upon sudden rise in spot prices of material or labor, nor should value attributable to its property be depressed by a similar sudden decline in the price level. ${ }^{28}$

Realmente, a correlação encargo-remuneração, por força do disposto nos arts. 175 , parágrafo único, III, da CF, e $9^{\circ}, \S 4^{\circ}$, da Lei $\mathrm{n}^{\circ} 8.987 / 95$, deve ser preservada durante toda a execução do contrato de concessão.

Ao exercer o controle de legalidade, o Poder Judiciário não poderá, nessa delicada missão, substituir-se ao processo técnico de fixação da tarifa

\footnotetext{
27 Revista de Direito Administrativo, v. 51, p. 438/439.

${ }_{28} 295$ U.S. 662, in The Supreme Court Reporter. St. Paul: West Publishing Co., 1935. v. 55, p. 894.
}

A\&C R. de Dir. Administrativo \& Constitucional, Belo Horizonte, ano 8, n. 33, p. 161-192, jul./set. 2008 
elaborado pelo órgão competente mas, como acentuado por Guimarães Menegale, em lição já invocada neste trabalho, procederá ao exame se da adoção de tais critérios e elementos técnicos resultou violação ao princípio da justa remuneração do capital. ${ }^{29}$

Cabe, aqui, recordar o voto proferido pelo Justice Harlam no célebre Smyth v. Ames Case, quando diz, verbis:

But it is equally true that the corporation performing such public services, and the people financially interested in its business and affairs, have rights that may not be invaded by legislative enactment in disregard of the fundamental guaranties for the protection of property. The corporation may not be required to use its property for the benefit of the public without receiving just compensation for the services rendered by it. How such compensation may be ascertained, and what are the necessary elements in such an inquiry, will always be an embarrassing question. ${ }^{30}$

$2^{\circ}$ ) Os bens reversíveis são aqueles necessários à continuidade do serviço objeto da concessão, excluindo-se os demais, estranhos à exploração dos serviços concedidos, que integram o patrimônio privado do concessionário.

O contrato de concessão deve prever a cláusula de reversão, nos termos do art. 23, X, da Lei $\mathrm{n}^{\circ} 8.987 / 95$, esclarecendo quais os bens que, finda a concessão, serão transferidos ao concedente e em que condições deverá a mencionada transferência efetivar-se.

$3^{\circ}$ ) Verificada a encampação, tem o concessionário direito à justa indenização, que deve compreender não somente a recomposição dos investimentos ainda não amortizados pela remuneração estipulada no contrato administrativo, bem como o próprio lucro que o concessionário deveria auferir com a exploração do serviço concedido, ora extinto pela encampação, considerando-se o prazo restante para o término da concessão.

Realmente, consoante dispõem os arts. $5^{\circ}$, XXIV, e 175, parágrafo único, I, da CF/88 c/c com o art. 37 da Lei n ${ }^{\circ}$ 8.987/95, a indenização ao concessionário em razão da encampação deverá ser justa e, na ausência de critérios específicos estipulados pelo legislador, prevalece o comando constitucional que protege o direito de propriedade e o respeito às garantias do direito adquirido e do ato jurídico perfeito (art. $5^{\circ}$, XXXVI, da CF).

Assim, omisso, no ponto, o contrato, nada impede que a apuração da indenização obedeça ao disposto na lei da desapropriação.

\footnotetext{
29 Revista Forense, v. 133 , p. 52-53.

30 In: The Supreme Court Reporter. St. Paul: West Publishing Co., 1899. v. 18, p. 433-434.
}

A\&C R. de Dir. Administrativo \& Constitucional, Belo Horizonte, ano 8, n. 33, p. 161-192, jul./set. 2008 
A respeito, averba o saudoso Ministro Aliomar Baleeiro, verbis:

"Justa" indenização - O art. 151, transcrito, não faz alusão ao valor do investimento, para efeitos de desapropriação, encampação ou reversão. Dispõe, apenas, expressa e exclusivamente, sôbre as tarifas de exploração, quer para remuneração justa e não excessiva do capital, quer para melhoria e expansão dos serviços.

Uma lei que adote o custo histórico, quer para fixação de tarifas, quer para encampação, só será constitucional se o processo por ela estabelecido para o cálculo garantir a "justa remuneração do capital”, no primeiro caso, e a "justa indenização", no segundo, salvo estipulação em contrário. A apreciação do resultado será decisiva.

Não só por interpretação analógica e sistemática se deverá chegar a essa conclusão, mas também, no silêncio do art. 151, intérpretes e aplicadores ficam adstritos a buscar, nos dispositivos expressos da Constituição sôbre e garantia ao direito da propriedade, a chave do entendimento do texto para aquêles casos especiais do direito administrativo.

Se o constituinte não estabeleceu regras especiais para fixação do valor dos investimentos realizados pelos concessionários de serviços públicos, para efeitos de reversão e encampação dos respectivos bens e instalações, evidentemente prevalecem os dispositivos constitucionais que, em caráter geral, disciplinam o direito de propriedade, dos direitos adquiridos, os casos e modos de desapropriação. ${ }^{31}$

Nesse sentido, o voto proferido pelo Ministro Rodrigues Alckmin, relator do RE n ${ }^{o}$ 75.930-GO, quando decidiu a Suprema Corte, verbis: "Se a encampação ou reversão não se efetivar nos termos do contrato ou de acordo entre concessionários e autoridade, o problema deverá ser resolvido pelos princípios e norma da desapropriação, aplicando-se à avaliação do investimento todos os métodos idôneos à apuração de indenização justa..." 32

E, para concluir, o magistério autorizado do Mestre Pontes de Miranda quando diz, verbis:

Nenhuma lei brasileira pode ser interpretada ou executada em contradição com os enunciados da Declaração de Direitos, nem em contradição com quaisquer outros artigos da Constituição de 1967; porém alguns dos incisos do art. 153 são acima do Estado, e as próprias Assembléias Constituintes, em emenda, não os podem revogar ou derrogar. Tais incisos são os que contêm declaração de direitos fundamentais supra-estatais. ${ }^{33}$

\footnotetext{
31 Revista Forense, v. 197, p. 51-52.

32 RTJ, v. 68, p. 541.

33 In: Comentários à Constituição de 1967 com a emenda $n^{\circ} 1$ de 1969. 2. ed. rev. São Paulo: Revista dos Tribunais, 1970. t. IV, p. 624, "c".
}

A\&C R. de Dir. Administrativo \& Constitucional, Belo Horizonte, ano 8, n. 33, p. 161-192, jul./set. 2008 
Com efeito, essa é a melhor exegese dos artigos Constitucionais invocados, a que melhor atende à sua finalidade e ao próprio espírito da Constituição, o que não deve ser desprezado pelo intérprete. Scire leges non est verba earum tenere, sed vim ac potestatem (CELSO, Dig. 1, 3, 7).

Nesse sentido, ademais, a distinção no direito constitucional americano entre a interpretação em sentido estrito e a construction, na lição de Thomas Cooley, verbis: "Construction, on the other hand, is the drawing of conclusions, respecting subjects that lie beyond the direct expressions of the text, from elements known from and given in the text; conclusions which are in the spirit, though not within the letter of the text." ${ }^{44}$

Da mesma forma, o ensinamento de William Blackstone, verbis: “(...) the most universal and effectual way of discovering the true meaning of a law, when the words are dubious, is by considering the reason and spirit of it; (...)".35

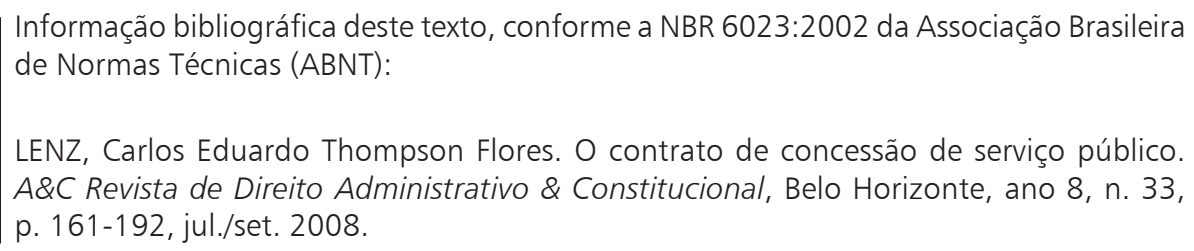

LENZ, Carlos Eduardo Thompson Flores. O contrato de concessão de serviço público. A\&C Revista de Direito Administrativo \& Constitucional, Belo Horizonte, ano 8, n. 33, p. 161-192, jul./set. 2008.

\footnotetext{
34 In: A Treatise on the Constitutional Limitations. 7. ed., p. 70.

35 In: Commentaries on the Laws of England. Philadelphia: J. B. Lippincott Company, 1896. v. 1, p. 60, n. 5.
}

A\&C R. de Dir. Administrativo \& Constitucional, Belo Horizonte, ano 8, n. 33, p. 161-192, jul./set. 2008 